\title{
Kernos
}

Revue internationale et pluridisciplinaire de religion grecque antique

$27 \mid 2014$

Varia

\section{Endowed Eponymous Festivals on Delos}

\author{
Joshua D. Sosin
}

\section{OpenEdition \\ Journals}

\section{Electronic version}

URL: http://journals.openedition.org/kernos/2276

DOI: $10.4000 /$ kernos. 2276

ISSN: 2034-7871

\section{Publisher}

Centre international d'étude de la religion grecque antique

\section{Printed version}

Date of publication: 1 November 2014

Number of pages: 127-157

ISBN: 978-2-87562-055-2

ISSN: 0776-3824

\section{Electronic reference}

Joshua D. Sosin, «Endowed Eponymous Festivals on Delos », Kernos [Online], 27 | 2014, Online since 01 October 2016, connection on 10 December 2020. URL : http://journals.openedition.org/kernos/ 2276 ; DOI : https://doi.org/10.4000/kernos.2276

This text was automatically generated on 10 December 2020.

Kernos 


\title{
Endowed Eponymous Festivals on Delos
}

\author{
Joshua D. Sosin
}

In $302 \mathrm{BC}$, Stesileos son of Diodotos, a prominent Delian, endowed 1500 drachmas to fund annual dedication of a phiale, to Aphrodite. ${ }^{1}$ He was an early adopter of what would become a popular economic and religious gesture on the sacred island. Over much of the next century Delos saw the creation of more than two dozen such endowments, ${ }^{2}$ which underwrote, scholars agree, festivals, nearly all of them eponymous: The Antigoneia, Eutycheia, Philonideia, Ptolemaieia, Stesileia, etc. This is the highest known concentration of both endowments and eponymous festivals from any single Hellenistic city. ${ }^{3}$ The Delian practice seems to illustrate a pattern of self-aggrandizement, by both royalty and non-, of such scale, pace, and intensity that it is striking even by ancient standards of humility.

2 It has not been observed, however, that Delian epigraphy does not refer unambiguously to these ritual acts as named festivals. Apart from a very few exceptions discussed below, we do not find proclamations "at The Stesileia," expenditure on items used "at The Ptolemaieia," Eutycheia," sale of hides from animals sacrificed at "The Antigoneia," or the like. The reason, I urge, is that the eponymous festivals thought to have been sustained by these endowments did not exist as such.

3 Ritual clearly did, and it was underwritten by endowments. A person dedicated money, which was lent at interest of ten percent ${ }^{9}$ and the returns used each year to dedicate a phiale or similar object and/or to conduct other ritual. Decrees honoring founders or enabling their endowments, such as we find elsewhere,$^{10}$ are unattested on Delos. Instead, we find inventories of dedications, ${ }^{11}$ records of lending and collection, ${ }^{12}$ disbursement of funds to ritual administrators, ${ }^{13}$ even arrangement of some endowed funds under common financial administration. ${ }^{14}$

4 Founders were Delians and aliens, men and women, ${ }^{15}$ and Hellenistic royalty. The last have drawn most attention from scholars, but the practice was home-grown. The first attested endowment was established by a Delian, Mikythos, perhaps around 310 BC. ${ }^{16}$ 
Stesileos' came next. Hellenistic royalty, and at least one high ranking adjutant, joined later; the first Ptolemaic endowment was established in $280 .{ }^{17}$ And for about two generations thereafter a roughly equal mix of royalty and non followed suit. Some fifty years after Stesileos' dedication, his daughter Echenike established an endowment. ${ }^{18}$ Perhaps around $240 \mathrm{BC}$, another wealthy and pious Delian woman, Philonis, created another, ${ }^{19}$ as did Nesiades and Gorgias, shortly after. ${ }^{20}$ About the other non-royal founders we are generally ignorant: for example, the Sopatros who established an endowment of an unknown size perhaps in 229, is only a name. ${ }^{21}$ Of known aliens, an Aitolian, Nikolaos, established an endowment in 252;22 likewise Eutychos of Chios, long conjectured to have been a banker or financier, about twenty years later. ${ }^{23}$

5 We know little of founders' motivations. But of the non-royal founders, Stesileos and his family do seem to fit a recognizable profile. He was archon in 305, choregos in 284 and 280; ${ }^{24}$ his son Diodotos served as ambassador, hieropoios, prodaneistes, and lampadarch in the $280 s ;{ }^{25}$ in 250 his daughter Echenike endowed sacrifice to Apollo and Aphrodite (above n. 18). He was not only politically engaged, but pious as well, and his piety extended beyond the endowment. By 304, he had dedicated not only a statue of Aphrodite, ${ }^{26}$ but also, it is thought, the sanctuary and small temple in which she resided. ${ }^{27}$ This stood at the northern edge of the theater quarter ${ }^{28}$ its entry apparently flanked by statues of his parents. ${ }^{29} \mathrm{~A}$ third statue was dedicated there by his daughter Echenike. ${ }^{30}$ Several dedications from the period of independence are from members of Stesileos' family ${ }^{31}$ The place "was saturated with the presence of Stesileos, in the form of his pious dedication, and the aged parents he chose to honour out of the fortune they had passed on to him." 32 Thus, the entire sanctuary is thought to be private, a family affair, much like the nearby, and later, Sarapeion A. ${ }^{33}$ Durvye has suggested that Stesileos' actions blended piety and more secular aspirations, by providing a gathering space for a "political group" and reaffirming the status and power of his prominent family. ${ }^{34} \mathrm{Here}$, in other words, are the actions of a well known type, an elite benefactor, ${ }^{35}$ for whom piety, philanthropy, politics, and the enhancement of personal and familial status are authentic and overlapping concerns. This is not a controversial idea; ${ }^{36}$ endowments, like most such benefactions, are generally thought to have projected founders' power to local audiences. An annual eponymous festival sent a clear message, demanded recognition, affirmed the prestige of founders and families. Establishing a private sanctuary at the same time only underlined this message. As gestures of political self-representation, therefore, the royal and nonroyal endowments look alike. The former have long and often been thought to celebrate and advertise major military victories in the Aegean theater; ${ }^{37}$ to manifest "religious policies" that were "part of an effort to consolidate ... close relations" ${ }^{38}$ with subject cities; to be an act of "pious self-advertising investment;" 39 to have been established "for the sole purpose of glorifying the new powers of the time, who craved the international recognition and prestige these gatherings could bring." ${ }^{40}$ Thus, the royal and non-royal endowments are thought to have aimed at the same effect.

But these endowments were too small to have garnered much international prestige. We know or can infer the capitalization of ten endowments (I.Delos 366.A.131-134); the smallest was 1500 drachmas, the largest 8700, and most between 3000 and 4000. Stesileos' fund, the smallest of the lot, earned but 150 drachmas per year, enough to acquire a phiale and little or nothing else. The annual return of Philonis' endowment, the largest attested and more than twice the size of most, was roughly equivalent to expenditure on wine alone for the annual festival at the Carian village of Kypranda (by Kaunos). ${ }^{41} \mathrm{~A}$ royal 
endowment that earned a few hundred drachmas and spent more than 100 of them on a phiale, could not buy much religion with the balance. The endowments underwrote ritual celebrations to be sure, but nothing like a festival befitting the honor of a king..$^{42}$ These 'festivals' were meant to be witnessed primarily by the gods. Their modest scale did not conduce to ostentatious, political machination and propaganda. ${ }^{43}$ Their size, then, sets them apart from the eponymous festivals of the Hellenistic world that we know so well.

7 And yet their names, The Stesileia, Eutycheia, Ptolemaieia, etc., do call to mind the small but well known number of eponymous endowed festivals from elsewhere in the Hellenistic world: ${ }^{44}$ The Leonideia at Pharsalos, Koan Pythokleia, Delphic Alkesippeia and Attaleia and Eumeneia. ${ }^{45}$ These eponymous festivals were not "the cult of So-and-so" (objective genitive) but "So-and-so's cult" for some deity, ritual offered to gods by a polity in the name of the men who provided the resources to fund it. The adjectival ending denoted a ritual's originator and funder rather than its object or recipient. Of course, the latter sense was also, and more typically, conveyed by the same: e.g. the Magnesian Leukophryeneia or Alexandrian Ptolemaia. These were two distinct kinds of eponymity, indicated by the same type of adjective. Such ambiguity was tolerable, understandable, and probably a natural development of the growth in private financing of public religion; Delphians will have had little difficulty remembering that the Alkesippeia was cult established, paid, and named for Alkesippos rather than cult offered to Alkesippos.

On Delos, however, the adjective was also used in a different way. The earliest of the endowments was established, around the time of independence, by Mikythos. Dedications offered via his fund were inventoried as kylikes mikytheioi, skaphia mikytheia, or plain mikytheia. ${ }^{46}$ Likewise, dedications funded by Stesileos' endowment were called poteria stesileia ${ }^{47}$ and officials called that fund the stesileion. ${ }^{48} \mathrm{~A}$ stesileion, then, was the fund that paid for offerings and an offering that was paid for by the fund. The hieropoioi did not record a loan of money that Echenike donated "for The Echenikeia" or some such, but rather "for a sacrifice to Apollo and Aphrodite." ${ }^{49} \mathrm{Her}$ fund was itself referred to as "the echenikeion. ${ }^{50}$ Likewise, the gorgieion paid for phialai gorgieioi $;^{51}$ the "money that Nesiades dedicated" was the nesiadeion; 52 Philonis' endowment was called the philonideion ${ }^{53}$ and underwrote some form of ritual, including annual dedication of an object also called simply a philonideion, or else a skaphion philonideion, or poterion philonideion. ${ }^{54}$ When the same Philonis dedicated a thymiaterion, by a separate initiative, it was recorded as a "dedication of Philonis," not as a philonideion: it came directly from her, not from her eponymous fund. ${ }^{55}$ Objects dedicated via an endowed fund might be said to come from the founder ${ }^{56}$ which does not mean that objects dedicated directly by an individual would be said to have come from his or her endowment. Thus, just as The Alkesippeia was ritual funded by Alkesippos, stesileia were dedications funded by the stesileion, which was endowed by Stesileos. This nomenclature is well known, ${ }^{57}$ but its importance underappreciated.

Scholars have referred to, say, "The Echenikeia" for good reason. In 207 BC the hieropoioi recorded several disbursements to epistatai for what appear to be eponymous festivals so named (I.Delos 366.A.131-134):

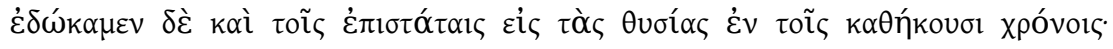

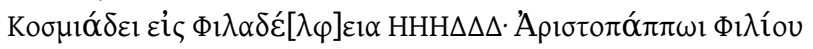

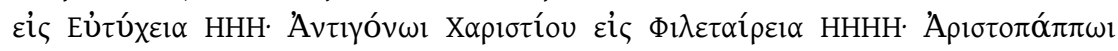

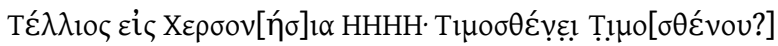

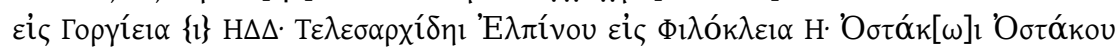

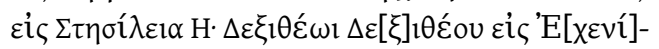




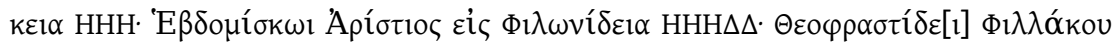

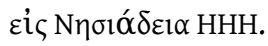

10 This seems to refer unambiguously to eponymous festivals. But no one appears to have

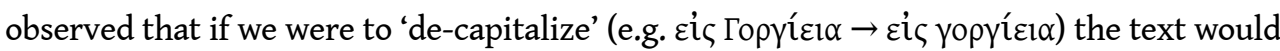
make no less sense. Whatever the gorgieion paid for, whether a phiale or a victim, was

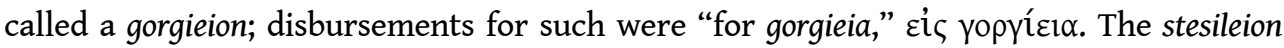
yielded 150 drachmas per year, which went "for stesileia" and purchased one phiale; the echenikeion yielded 300 drachmas, which went "for echenikeia," which in this case were not phialai but some other rites (sacrifice, libations, vel sim.). All of these fell under the broad rubric thysiai, not solely the sacrifice of victims (Stesileos' endowment did not fund such), but rather, rites, ceremony, offerings in a broad sense. So, there was ritual; there was celebration; there was dedication. But nothing in this passage requires the existence of endowed eponymous festivals per se.

11 A common expression found elsewhere in the hieropoioi accounts seems to record phialai coming "from (celebrations) of the Stratonikeia" or the like, e.g. I.Delos 366.A.53-55: koì

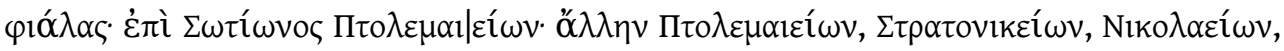

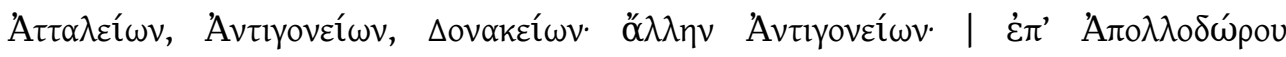

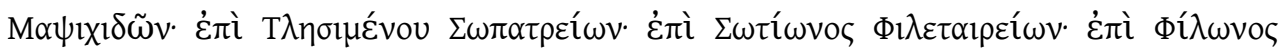
$\Delta \eta \mu \eta \tau \rho \imath \varepsilon i \omega v$. But for officials responsible for tracking hundreds of these objects, a somewhat different construction would be understandable. Since each individual dedication was known as, say, 'a ptolemaieion' and the vast stores of them could be referred to collectively as 'ptolemaieia,' these might well be reckoned, "another of the ptolemaieia, and of the stratonikeia," etc. Such a construction suits grammar and is also in keeping with ancient religious sensibility: to both god and polity an object's dedicator (say, Nikolaos) was a more important piece of information, and was more often inscribed, than the occasion of its dedication (say, the Nikolaeia). Since a nikolaeion was an object dedicated by Nikolaos via his endowment, to record ó $\lambda \lambda \eta v$ viko $\lambda \alpha \varepsilon i ́ \omega v$ was simply to indicate another of the dedications that Nikolaos made via his eponymous fund. Thus, here too, the Greek need not refer to a festival, and it makes better ritual sense if it refers to a dedicator.

Elsewhere, the inventories are explicit about this. Endowment phialai are often recorded alongside phialai that were dedicated by the Delian trittyes, the Mapsichidai, and the Thyestadai and Okyneidai, e.g. I.Delos 366.84-85 (207): ö $\lambda \lambda \eta v ~ \Pi[\tau o \lambda \varepsilon \mu] \alpha 1 \varepsilon i ́ \omega v \cdot \dot{\varepsilon} \pi i ̀ ~ X \alpha \rho i ́ \lambda \alpha$

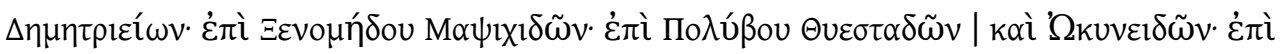

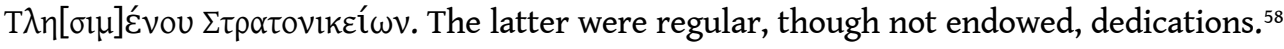
The trittyes were agents, dedicators, and not occasions; the genitives indicate that the dedications were theirs, in the strict sense of having been offered by them. In this

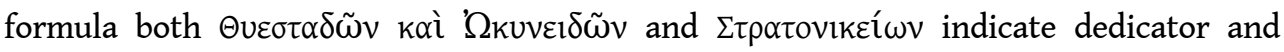
neither refers to occasion. Like the genitive, the adjectival ending in -eion also tells of dedication, in this case indirect, by the person for whom an endowment is named. This was the compressed language of accounting. But elsewhere, the inscriptions show the equivalence more explicitly, deploying the same boilerplate to record "other phialai which the Thyestadai and Okyneidai dedicated" and "other phialai which the Deliades dedicated, King Ptolemy having contributed the choreia." ${ }^{59}$ These are merely the verbose

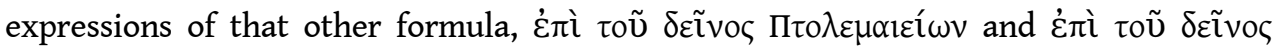

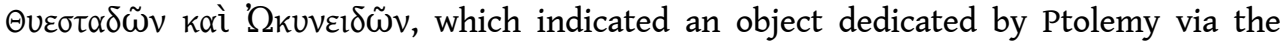
ptolemaieion and an object dedicated, without such intermediation, by the Thyestadai and 
Okyneidai. The same logic underpins both formulas and shows that the Delian accounts recorded the dedicator and not the occasion. There was no dedication of a "phiale from The Ptolemaieia." There were no endowed eponymous Ptolemaieia; ${ }^{60}$ there was an endowment to pay for regular ritual that included dedication of ptolemaieia, a different thing.

There were eponymous funds (e.g. stesileion, gorgieion, etc.), which endowed offerings that were referred to by the same convention (collectively, stesileia, gorgieia, etc.). These were regular, simple, and modest offerings that accompanied a ritual performance of the Deliades. This endowed ritual at Delos was not like the Delphic Alkesippeia or Pharsalian Leonideia or even the Delphic Attaleia and Eumeneia. The Delian gesture was smaller, humbler, less ostentatious than the grand eponymous festivals of the Hellenistic world. Founders gave names to their dedications, which was normal religion, and to the endowments that paid for those dedications, which was expedient administration. But the Greek does not indicate that Delians attended festivals called 'The Stesileia' or the like. Endowed ritual with funds and dedications named for the founders, yes; endowed festivals named for their founders, no.

in scale, sensibility, and terminology, the Delian ritual looks more like the modest endowed family cult that we know so well from the Hellenistic period. ${ }^{61}$ Even the more ambitious endowed family associations did not sustain large public festivals. Diomedon's testamentary endowment at Kos supported family gatherings after his death and carefully regulated family members' use of the endowed sacred precinct for weddings. ${ }^{62}$ Epikteta's testamentary endowment on Thera offered similar support and also reserved the precinct for family weddings. ${ }^{63}$ Poseidonios of Halikarnassos endowed a field, with courtyard, garden, and memorial to support annual cult by his assembled family members. And while he did stipulate that on the first day of the annual celebration the agathos daimon of himself and of his wife Gorgis should receive a ram, there was no eponymous festival and the first order of business was to be a sacrifice to the agathe tyche of his presumably deceased parents. ${ }^{64}$ When Kritolaos of Amorgos endowed games on the death of his son Aleximachos, the ritual was modest and restricted to the gymnasiumgoing elite; the endowment itself yielded only 200 drachmas per year. ${ }^{65}$ Most such endowments recognized the familial disruption of death with modest ritual; some supported familial growth through unions. By and large they did not do so with festivals named for the founders themselves. ${ }^{66}$

If the Delian endowments were a local manifestation of this wider phenomenon, then we might expect them to have been established to mark similar moments in their founders' lives. Unfortunately, as rich as Delian prosopographic data are, we lack the information to reconstruct detailed family histories. In the case of the royal endowments, however, we are better informed. Now, in no instance is the purpose or occasion of an endowment's founding stated. But some cases admit of reasonable speculation. The hieropoioi started recording phialai contributed by Philetairos in $262 \mathrm{BC},{ }^{67}$ meaning that the endowment was established in 263, the year of Philetairos' death. Some have thought that Philetairos established the endowment himself, ${ }^{68}$ in support of a festival named for himself, in honor of himself. But several royal endowments were founded in or around the year of their eponym's death, so that it is simpler to conclude, as some have, that Eumenes I established the fund upon his uncle's death and his own succession to the Attalid throne. ${ }^{69}$ If so, then the eponym was not self but family member, the act not self-promotion but right piety, consistent with Eumenes' apparent dedication of a statue of Philetairos at 
about the same time. ${ }^{70}$ If so, then this was a minor departure from Delian practice, inasmuch as the formal dedicator was held to be not the endowment's founder, but the individual on whose behalf and under whose name someone else established the fund. Eumenes gave the money that allowed Philetairos to contribute phialai postumously. But if these funds were established on the occasion of important family events, as I have suggested, then this endowment remained otherwise true to convention, inasmuch as it was founded in pious response to Philetairos' death.

Similarly, in 246, the third of the Ptolemaic endowments was established. ${ }^{71}$ This was the year in which Philadelphos died and Euergetes ascended to the throne. Some have viewed this as somehow announcing or enforcing Euergetes' legitimacy. ${ }^{72}$ But any such measures are likely to have been carried out on the home front and at scale, not on Delos with a modest rite, whose perpetuation by endowment entailed a year's delay before first offering. As pious observance of a family member's death, on the other hand, the gesture is understandable.

There may be a pattern. The first stratonikeion was dedicated in 252, its endowment having been created in the previous year. ${ }^{73}$ The fund was named for the daughter of Demetrios Poliorketes, sister of Antigonos Gonatas, ${ }^{74}$ wife of first Seleukos Nikator and then his son Antiochos. ${ }^{75}$ It has been suggested that the endowment was established to celebrate Antigonos' naval victory off Kos - which may have taken place in 255, or even earlier; ${ }^{76}$ in either case the delay is unexplained and should raise doubts. Whatever the date, though, a major naval victory seems a bizarre occasion for Antigonos, if he was the author of the endowments, to have honored his sister, especially with a modest ritual that few would ever see. On the other hand, if Stratonike died in 254, as has been suggested and often accepted as plausible, though never proved, ${ }^{77}$ the subsequent creation of the endowment to produce dedications offered "on her behalf" 78 would have been an intelligible show of piety and a reasonable religious response to her death.

In that same year Antigonos is thought to have established an eponymous endowment in honor, the assumption goes, of himself and in celebration of his earlier naval victory off Kos. But scholars agree that Antigonos' son Demetrios II married Stratonike, the daughter of Antiochos I, in the mid 250s; Tarn's conjecture that the marriage took place in 253 has found followers if not proof. ${ }^{79}$ Demetrios' marriage may well have been worth celebrating. No one could have known at the time that the union would end unhappily. ${ }^{80}$ Demetrios' father Antigonos Gonatas had also married a Seleucid princess. ${ }^{81}$ Now, another such alliance opened the door to future succession.

I suggest, then, that the two Antigonid endowments may have been created not in celebration of a military success, not to advertise imperial might, but rather to acknowledge two religiously charged domestic and dynastic moments, one severing a tie to the Seleucids and another forging a new one; these may have taken place in 254 and/or 253, but in any case quite close to each other, and just before the endowments were established on Delos. Antigonos was in his sixties. He had a son and heir in Demetrios II and, with his son's new well-placed marriage to Stratonike, Antigonos had done what he could to secure the family's next generation. At this critical moment, I suggest, Antigonos established a pair of endowments, the one observing the death of his sister Stratonike with annual dedication of stratonikeia, the other celebrating the marriage of his son Demetrios II with antigoneia, named perhaps for the founder himself, Gonatas, but perhaps instead for his homonymous forebear. As commemoration of a major military success such a modest affair - not to mention its eponymity after a woman - would have 
been laughable, ill-befitting the grandeur of the king and occasion, beneath the honor and thanks owed to the gods. As family ritual, however, such a gesture would have been understandable, respectable, appropriate.

An endowment named for a Demetrios appears to have been founded in $238,{ }^{82}$ the year after Demetrios II succeeded his father Antigonos Gonatas. It might be tempting to suppose that the demetrieia dedicated via this endowment were regarded as having been dedicated by Demetrios II himself. But if Antigonos, only a few years before, had established an endowment in the name of his own grandfather, as I have suggested, then it could have been reasonable for Demetrios II to have done the same. ${ }^{83}$ It is at least possible, I suggest, that the antigoneion and demetrieion were established by Antigonos Gonatas and Demetrios II, not in their own names but rather in those of their forebears Monophthalmos and Poliorketes - not that subsequent generations of Delians need have known the difference, or cared. ${ }^{84}$

We might find a similar explanation for the occasion of the founding of the second Ptolemaic endowment in 249.85 Tarn saw its creation as a kind of bold political statement by Ptolemy, who he thought in that year had regained control of the Aegean from Antigonos. ${ }^{86}$ Reger is more cautious: "Since ... there is no apparent non-military event (a royal accession, death, marriage, etc.) with which to associate the Ptolemaieia [II] in 249 B.C., it may well be that the festival celebrated the recovery of the islands, and perhaps even a military victory. But this matter remains very obscure." ${ }^{87}$ Champion seems to suggest commemoration of military victory: the second and third "Ptolemaieia festivals ... were established on Delos in 249 and 246, following a Ptolemaic naval victory over Gonatas, sometime around 250." ${ }^{88}$ Again, one doubts the efficacy of this ritual as propaganda and wonders, instead, whether the occasion was the betrothal of Ptolemy (III) Euergetes to Berenike (II), upon the death of her father Magas, king of Cyrene, which may have taken place in $250 .{ }^{89}$ The union was significant, if not lasting.

With the religiously charged moments of death and marriage looming so large as possible occasions for the creation of these modest royal endowments, the origins of two others may find explanation. In $268 \mathrm{BC}^{90}$ Hermias the Ptolemaic nesiarch ${ }^{91}$ endowed an offering to Arsinoe Philadelphos, Apollo, Artemis, and Leto. ${ }^{92}$ A recent survey of the debate over the date of Arsinoe's death, concludes that early July 268 is more likely (than 270) and most favored ${ }^{93}$ It appears, however, that no one has found it significant that Hermias established this endowment in 268. Arsinoe was a favorite of men connected with the high seas, ${ }^{94}$ evident perhaps in her special association with Aphrodite Euploia. ${ }^{95}$ It would have been an understandable gesture of piety if this captain established an endowment in the name and honor of Arsinoe, following her death. The coincidence does not prove that Arsinoe died in 268, but it is suggestive. If the occasion was her death, it would not be the last time such moments were observed and commemorated with endowed ritual on Delos. And in any case, Hermias' endowment looks more like an expression of personal piety than an articulation of Ptolemaic policy.

23 The occasion of the earliest attested royal endowment on Delos is problematic. Apparently in $280 \mathrm{BC}$ the first Ptolemaic endowment was established. It is generally thought to have been created by Philadelphos, who was in this period active in honoring his father, ${ }^{96}$ not that we can point to a specific occasion. But in 281 Lysimachos, the husband of Ptolemy's sister Arsinoe (II), had fallen at Koroupedion. Not long after, Arsinoe married her half-brother Ptolemy Keraunos, a union inaugurated by the murder of her children and soon ended by his own death in $279 .{ }^{97}$ Arsinoe fled to Egypt, stopping 
first at Samothrace. ${ }^{98}$ We do not know her route, or the timing. But on one suggestion, she journeyed under escort of the Ptolemaic nauarch Kallikrates. ${ }^{99} \mathrm{He}$ was at the time no stranger to Delos. In 279 the hieropoioi declared that they had received from their predecessors two gold crowns dedicated by him..$^{100}$ These must have been offered in 280 or earlier. ${ }^{101}$ For Arsinoe, looking homeward in 279, ${ }^{102}$ a survivor of two disastrous dynastic unions, perhaps accompanied by the distinguished Ptolemaic naval officer, Delos may have have been a welcome way station. But, if she landed in 279 how can she have founded the endowment in 280 ?

In $274 \mathrm{BC}$ the hieropoioi could count six phialai dedicated by Ptolemy, covering 275, 274 and four other unspecified years. ${ }^{103}$ Similarly, in 240 BC the hieropoioi recorded receipt of 39 phialai, most dated by archon, several by epistates, and one with no indication of date, "bearing neither archon nor epistates." 104 Both measures put the first year of dedication at $279 \mathrm{BC}$, and so the date of endowment in 280. But the blank phiale is worrisome. Durrbach suggested long ago, and Bruneau and others admit the possibility, that the endowment could have been established in 279 and its first phiale paid for separately, promptly, ${ }^{105}$ in other words, in cash, up front, and not out of interest accrued. This is a reasonable proposition; what would the founder do who was in a hurry, wanted to get started right away but the timing of whose dedication did not square with a 12-month lending period? The creation of the first ptolemaieion in 279 by Arsinoe and/or Kallikrates just might be possible, provided that it was paid for separately. And if that were the case a dedicated phiale might not bear an inscribed indication of date. Perhaps the undated phiale was offered in haste, by a queen on the move, as the very first dedication of the new endowment.

Keraunos was dead and likely claimed no honor from Arsinoe. But her children had been slain only shortly before, by his hand, we are told, and in her very arms. ${ }^{106}$ Commemoration and retrospection were perhaps in order and on her mind, as I have suggested it was in the later endowments established on the occasions of royal deaths. And perhaps also a taste of the optimism that will have attended the endowments created on the occasion of royal unions. Now, Ptolemy and Arsinoe were not yet wed, ${ }^{107}$ and there is no evidence that either yet had the sibling union in mind. And while hindsight tells us that Arsinoe's homecoming proved important to the Ptolemaic dynasty, ${ }^{108}$ she will not have known as we do. But if Arsinoe stopped on Delos in 279, on the run - much as Leto had been when she arrived at Delos - and with no salvation but the royal family into which she was born and to whom she was returning, the creation of a modest endowed ritual named for the dynasty's progenitor, whose Alexandrian Ptolemaia were now either on the horizon or in recent memory, ${ }^{109}$ would have had obvious emotional and religious appeal. If the commemorative and celebratory logic of the later endowments applied here as well, then such a gesture would have made good pious sense. Even if the suggestion that Arsinoe may have established the first Ptolemaic endowment is not accepted, nothing about the endowment suggests grand celebration of military achievements or the like.

of the royal endowments whose dates of creation are clearly known, two have been the object of considerable scholarly attention, the Antigonid endowments that yielded dedications to Pan and the TheoiSoteres, both understood to support festivals, The Paneia and Soteria, both established in $245 .{ }^{110}$ The pair has long been thought to commemorate an Antigonid naval victory over Ptolemy at Andros. ${ }^{111}$ Champion has recently revived a suggestion of Will's that the festivals commemorated Antigonos' defeat of the Galatians at 
Lysimacheia a generation before, and were established in order to 'answer' the newly panhellenic Aetolian Soteria, to remind the world that he too had bested Galatians, and first. ${ }^{112}$ But, again, the audience and scale of the Delian ritual was small and cannot have reminded very many of very much. We may have another explanation to hand, for 245 was very likely the year in which Antigonos Gonatas secured Corinth by marrying his son Demetrios II to Nikaia, daughter of Alexander of Corinth. The ancient tradition characterized the union as a sham, part of an elaborate ruse, and either initiated but abandoned mid-ceremony, or else enacted but not consummated; "Although it is unlikely that the Antigonids ever intended the marriage to last, their offer of marriage must have seemed plausible to Nicaea." ${ }^{113}$ However we imagine Antigonid intentions and whatever may have happened, or not, at the ceremony or afterward, all we know is that Antigonos held Corinth until 243 and that we hear nothing more of Demetrios' wife. The silence is little surprise; sources for the episode, and the period, are hardly thick on the ground. If such unions had a history of pious recognition on Delos, then perhaps this one was the occasion of the endowment, and we are here reminded that not every devious stratagem recorded in Polyainos or Plutarch was true and that ulterior motives did not necessarily bar unions of convenience from pious recognition and ritual.

Of all of the Delian endowments, these two seem most atypical, most like - in nomenclature anyway - festivals named for the deities who received the cult. But here again, the Delian accounts do not refer unambiguously to The Paneia or The Soteria. We

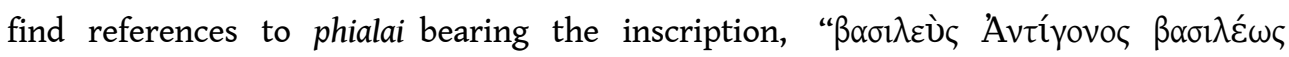

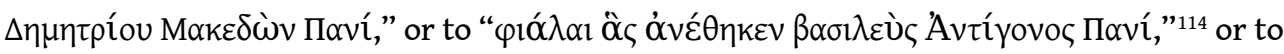
"another of the paneia." ${ }^{115}$ These dedications, then, were described much as Hermias' dedications to Arsinoe Philadelphos were; his endowment underwrote dedication of philadelpheia to a favorite goddess and Antigonos' paneia to a favorite god. Only two

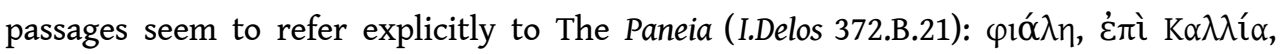

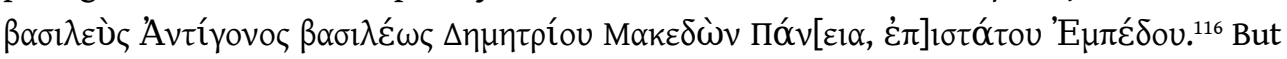
what is the syntax of the restored and grammatically dangling חó $v[\varepsilon ı \alpha$ ? The formula is jarring too. The same account records several other phialai dedicated via endowment, mentioning the divine recipient of the dedication, but not a festal occasion (I.Delos

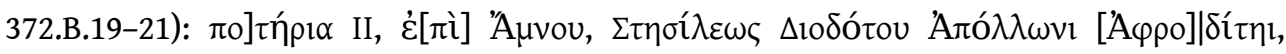

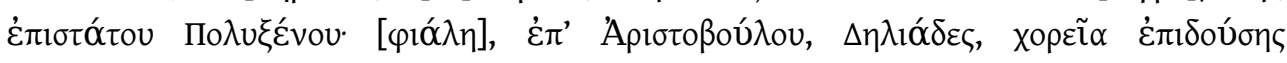

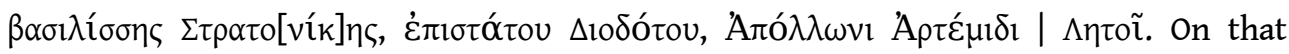

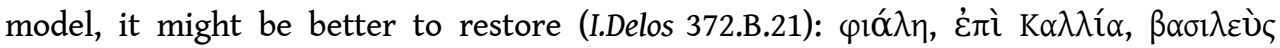

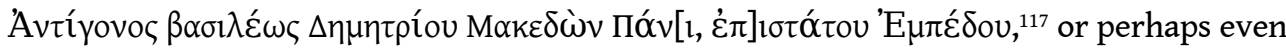

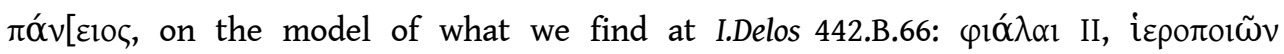

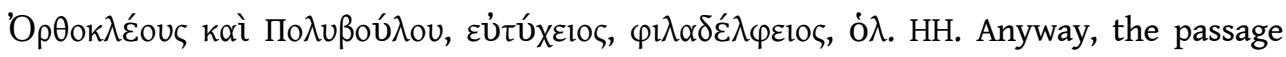
speaks only of a dedication to Pan and not of a festival named for him or anyone else.

The dedications to the Theoi Soteres are similarly problematic. Two accounts refer to phialai dedicated by Antigonos to these gods, but in both cases the receiving deities are entirely restored. ${ }^{118}$ No other entry refers to his dedication of a phiale to them. At I.Delos

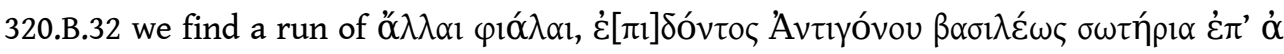

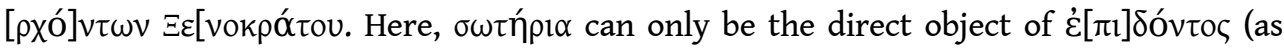

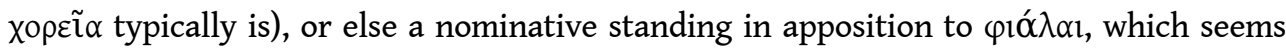
rather less likely. Most endowments funded song, dance, and a modest dedication; this one apparently funded dedications that were sometimes referred to as thank-offerings,

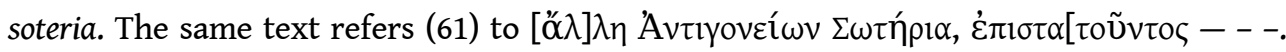


Under the prevailing interpretation this is unintelligible. Is this one festival or two? If two, then under what grammar does the Antigoneia appear in the genitive and the Soteria in the nominative or accusative? As given, the text is nonsense, does not construe. Instead, I urge, we have here a record of "another (phiale) of the antigoneia, a thank-

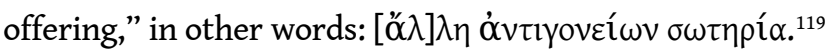

There is but one other entry thought to refer to The Soteria (I.Delos 380.72-93 [198?]): ${ }^{120}$

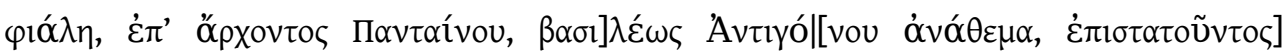

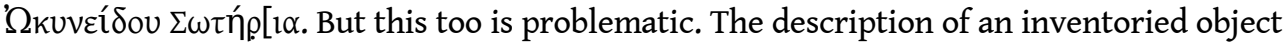
generally ends with the reference to the epistates. 'E conclude the entry and is followed by the next object. ${ }^{121}$ Thus, here, the phiale is either recorded as a thank-offering and unusually positioned after the end of the dating formula (a pió $\lambda \eta \ldots \sigma \omega \tau \eta{ }^{\prime} \alpha$ ), or else the thank-offering belongs with the subsequent entry. Alternatively, we could perhaps restore $\Sigma \omega \tau \tilde{\eta} \rho[\sigma$ l, on the assumption that Zeus Soter and Athena Soteira are the intended recipients of the thank-offerings (soteria); but in that case the omission of $\Theta \varepsilon$ in ৎ would be worrisome, as would be the fact that sole indication that the endowment offered dedications to the Theoi Soteres in the first place is a pair of restorations. The endowment funded the dedication of objects that were usually called simply phialai or dedications (anathemata) and sometimes called thank-offerings (soteria). On only two occasions do we find reference to "another of the soteria;" 122 it is only assumed that these came from The Soteria. The inventory may just as easily have recorded "another of the thank-offerings." When Delos decreed honors for Philokles King of Sidon around 280, these included the sacrifice of thank-offerings (soteria) on his behalf, to Apollo, Artemis, Leto, Zeus Soter, and Athena Soteira. ${ }^{123}$ So also, expenditure on "torches for the choros of the soteria" ${ }^{124}$ need not have gone toward any festival so named, nor even have referred to the Antigonid endowment, but rather to some ritual offering of thanks.

There were neither Paneia nor Soteria. Still, Antigonos, did act. But if celebration of military victory motivated him, then his gesture, I urge, was not in keeping with the other royal endowments at Delos. We need not accept Momigliano and Fraser's early date for the Battle of Andros to see the virtue of their observation that we do not strictly know Antigonos' motivation; it may have been "the recovery of Corinth - a famous and most celebrated event, or it may be some victory in the north which our miserable evidence does not record; or it may be some personal event (recovery from an illness?) to which the old king could have attributed more importance than his distant historians would allow"125-not the recovery of Corinth per se, I suggest, but the family union that accompanied it. Nor were his and the other modest ritual acts that were endowed at Delos established with an eye to international prestige. Or if they were, they can only have been ineffective. They were too small, too parochial. ${ }^{126}$ And if Gonatas meant the dedications somehow to answer the Aetolian's panhellenic festival, the Soteria, as Champion has suggested, then it was a feeble piece of propaganda, witnessed and heard by few.

The grand political and military events that have so long served to explain the occasion of these small ritual gestures are in most or all cases unrelated. Reger is in my view surely right to remind that "any argument that tries to see [the Delian endowments] all as answering the same needs is likely to be mistaken." ${ }^{127}$ Moreover, nothing indicates that this modest endowed ritual was ever meant to commemorate grand military exploits or was ever funded at a level so as to draw much recognition or prestige beyond the very narrow circle of ritual participants on the island. It is simplest, I urge, to understand the 
endowments as much more modest expressions of piety and to have been motivated in most, if not all, cases by familial events, as were so many other endowments of the age.

If the royal endowments were a part of this wider trend and closely tied to founders' family histories, could the others have been as well? We can do little more than speculate, and only in the case of the Stesileos with whom we began. With him as with the royal founders, the scope and dimension of his self-promotion was, it turns out, much more limited than has been thought. If I am right, then there was no eponymous festival. But neither was there a private temple or private hosting of political figures in Stesileos' own private sanctuary. ${ }^{128} \mathrm{He}$ very clearly dedicated the statue of Aphrodite: the hieropoioi recorded payment "to Ophelion, who held the contract to paint and adorn the statue of the Aphrodite whom Stesileos dedicated." ${ }^{129}$ But the temple was not 'his.' The same account indicates payment to a contractor for whitewashing the temple of the particular Aphrodite whom Stesileos dedicated, but it says nothing of a 'temple that Stesileos dedicated. ${ }^{130}$ If he had dedicated the temple as well, we should expect the account to have said as much. Moreover, the entries record state payments for upkeep of both image and temple, which alone ought to preclude private ownership. ${ }^{131}$ As much as a polity might care about the well being of private sanctuaries, ${ }^{132}$ there is no reason to think that Delos spent money to maintain a sanctuary owned by one of its citizens. We must conclude that neither temple nor statue was owned by Stesileos; ${ }^{133}$ that the sanctuary was Delian, public. If Stesileos had in fact dedicated the temple it would have been odd for the account to have mentioned him as dedicator of the goddess' cult statue, but to have ommitted that he had also dedicated her house. The temple's civic status, however, did not preclude Stesileos' receiving the honor of placing statues of his parents at its entrance. ${ }^{134}$ In fact, their appearance there calls to mind again the Hellenistic family endowments that I suggest were part of the same tradition that we see on Delos and the kind of occasions that may have inspired the creation of the royal endowments; perhaps one or both of Stesileos' parents had died shortly before. ${ }^{135}$

Thus, while Stesileos did not create a private sanctuary to accompany his endowment (as, say, Epikteta or Diomedon did), the occasion of the endowment looks rather like that of the modest endowed family religion that we find both elsewhere and, I suggest, with the Delian royal endowments. Similarly in keeping with the local tradition and wider trend is the small size of his fund - the smallest of those whose principal is known - which bespeaks authentic piety more than ambitous self-promotion; with a yield of only 150 drachmas per year, the intended primary witness to the ritual supported by this endowment was the god rather than the wider community. Stesileos' endowment did not differ in substance from the other non-royal funds on Delos. Nor, for that matter, are his and the other non-royal endowments distinguishable in any meaningful sense from the royal ones. They sustained similar ritual, on the same very small scale, possibly motivated by the same kinds of family events, and submitted to the same management. This Delian religious habit, whether in the hands of locals or not, was at root pious and parochial, offering little by way of international or even local recognition or prestige.

As closely as the royal endowments followed local tradition, they did innovate in small ways. For one thing, they seem to have introduced the concept of the endowment established by one person on behalf of another, who was to be regarded as both donor and dedicator. A single account could record phialai whose inscriptions declared that performances of the Deliades were underwritten "on behalf of Stratonike" and then indicate that "Stratonike contributed" twelve such. ${ }^{136}$ Someone else established the 
endowment on her behalf and in her name, such that 'she' was able to offer annual dedications. This was not the practice among the non-royal founders (unless we are to imagine, for example, that Stesileos established the stesileion on behalf of a homonymous relative or some such), but it appears to have been common among royal founders, perhaps even the default gesture. Second, when Hermias endowed rites to be offered not only to the Delian triad, Apollo, Artemis, and Leto, but also to the deceased Arsinoe Philadelphos, he introduced new usage to Delos. No other fund had yet been named for the recipient of ritual, rather than the dedicator. The philadelpheia yielded by the endowment were both named for (as, say, the ptolemaieia, demetrieia, etc.) and offered to the dead and deified queen. In this case, however, Hermias was inevitably recognized as the founder. ${ }^{137}$ Here, there is no slippage such as we find with the endowment created on Stratonike's behalf. For, in Arsinoe's case, the logic that the eponym, formally speaking, was the donor did not work; Stratonike might be regarded as a postumous dedicator, but no one will have entertained the notion that Arsinoe dedicated a phiale to her dead and deified self. The Antigonid endowment that provided dedications to Pan was the same; its dedications were paneia, named for the recipient of the ritual and not for the founder or any other 'donor' on whose behalf the endowment was created.

These innovations created a few minor oddities in the Delian accounts. As we have seen, stratonikeia were recorded as having been dedicated both by Stratonike and on her behalf. Antigonos, or whoever established this endowment for the purpose of dedicating stratonikeia, was thinking within a widespread framework that named ritual either for divine recipients or human honorees; Delian account keepers, on the other hand, thought in terms of a local administrative tradition by which the donor gave his or her name to the endowment, which paid for the ritual: the stesileion was the fund established by Stesileos, regardless of what or who prompted him to establish it. Following local practice, Delians might naturally think of the philetareion as underwriting dedications contributed by Philetairos, ${ }^{138}$ even if, as I suggest, the founder was his successor.

Cases in which Delians seem to refer to ritual underwritten by the royal endowments as festivals are very few. In two, and perhaps four, cases wood (for fuel) or torches were meant "for The Philokleia;" 139 a handful of passages refer, with different phrasing (genitive rather than dative), to "lamps for the chorus at(?) The Ptolemaieia" and several other of the alleged festivals. ${ }^{140}$ The same phrase is used also of The Aphrodisia, unambiguously a festival. ${ }^{141}$ But even here, inasmuch as the custom was to refer to all activities supported by the endowments (whether sacrifice or dedication of phialai) with the eponymous adjective in -eia, a person might find himself in need of certain materials "for the philokleia," i.e. "for the ritual activities supported by the philokleion." But this does not a festival make. Moreover, even such potentially ambiguous phrases - perfectly intelligible to Delians, I urge - are extremely rare. We also find expenditure on torches "for the chorus (held) on the eighth (of the month), ${ }^{142}$ or the fifteenth. ${ }^{143}$ This, I suspect, better fits the nature of these endowed rites; these were sacrifices fixed sustainably in the calendar but not as festivals. The remarkable fact is that the Delian accounts manage, over more than a century, and thousands of inventoried items, to avoid ambiguity almost entirely, and to maintain as clear a distinction as they do.

Delians' administrative rigor led them to develop an efficient shorthand for describing various aspects of endowed ritual, using the name of the dedicator - a natural choice in the domain - to derive a name for the endowed principal and dedications made via its yield. Who would not understand that a mikytheion was a dedication of Mikythos? At Delos 
in the late fourth and early third centuries, festivals named for individuals were scarce. So, confusion would not arise when officials spoke of multiple mikytheia. No one would mistake his modest dedications for a festival anyway.

Before long, though, Hellenistic kings and queens began to participate in a manner that slightly changed both the convention and its terms, in clear ways. Yet, even they were not tone-deaf to local convention. We might imagine that to an Antigonos or a Ptolemy, the institution may have seemed like a smaller, or analogous, version of a familiar gesture: the foundation of cult named after, in honor of, or even to, a king or deity. But if it did, we cannot tell, for they observed local protocol closely. Their prominence and spending power did not eclipse or transform local tradition. Antigonos did not swoop in and create giant endowments. Notwithstanding the minor changes that they seem to have introduced, royal founders do seem to have appreciated that this was a modest gesture, family-related, valuable and important in and of itself as ritual; that this was not the place or the institution for grand ostentation and lavish eponymous festivals.

Neither do we find Delians emulating at home what was more common practice elsewhere. They do not appear to have endowed sacrifice in others' names or to have transformed their modest recurring ritual into something more like Alkesippos' eponymous festival. Not even the prominent Stesileos did so. Rather, they stuck by their tradition, accommodated royal initiative under existing administrative and ritual apparatus, happy no doubt for the infusion of available credit and the honor, but not seeking to flatter kings by naming festivals for them, not naming festivals for themselves, not even elevating such ritual to the level of festival at all, and certainly not serving as a stage on which the rich and powerful propagandized to the world. They were content with the god and a few others as witnesses to their piety, and to honor their own in their own honorable way.

\section{Abbreviations}

BRINGMANN, Schenkungen: K. BRINGMANN et al. (eds.), Schenkungen hellenistischer Herrscher an griechische Städte und Heiligtümer, Berlin, 1995, vol. 1.

BRUNEAU, Recherches: Ph. BRUNEAU, Recherches sur les cultes de Délos à l'époque hellénistique et à l'époque impériale, Paris, 1970.

CARNEY, Women and Monarchy: E.D. CARNEY, Women and Monarchy in Macedonia, Norman, 2000.

Guide de Délos ${ }^{4}$ : Ph. BRUNEAu et al. (eds.), Guide de Délos, $4^{\text {th }}$ ed., Athens, 2005.

HAMMOND - WALBANK, Macedonia: N.G.L. HAMMOND, F.W.WALBANK, A History of Macedonia, Oxford, 1988, vol. III.

LAUM, Stiftungen: B. LAUM, Stiftungen in der griechischen und römischen Antike: Ein Beitrag zur antiken Kulturgeschichte, Leipzig, 1914.

TRÉHEUX, Études: J. TRÉHEUX, Études critiques sur les Inventaires de l'Indépendance délienne, Thèse, Paris, 1959.

VIAL, Délos indépendante: C. VIAL, Délos indépendante [= BCH suppl. 10], Paris, 1984.

ZIEBARTH, “Delische Stiftungen": E. ZIEBARTH, “Delische Stiftungen," Hermes 52 (1917), p. $425-441$. 


\section{NOTES}

1. BRUnEAU, Recherches, p. 342-343; ZIEBARTH, "Delische Stiftungen," no. 2. The first dedication was made in 301 (I.Delos 298.A.96 [240 BC]), which suggests that the capital was donated and endowed in 302 .

2. The fullest treatment remains Bruneau, Recherches,p. 515-583. Significant early effort by E. SCHUlHof, "Fouilles de Délos," BCH 32 (1908), p. 5-132, no. 21 (between p. 82-83, esp. p. 101-132 [later I.Delos 366.A]. LAUM, Stiftungen, included four: nos. 53-56. More comprehensive: ZIEBARTH, "Delische Stiftungen"; see also id., "Beiträge zum griechischen Recht: 2. Juristisches aus griechischen Inschriften," Zeitschrift für vergleichende Rechtswissenschaft 19 (1908), p. 269-312, at p. 298-304, which followed "1. Die Stiftung nach griechischem Recht," Zeitschrift für vergleichende Rechtswissenschaft 16 (1906), p. 249-315, with addenda at p. 470-475. J. Tréheux did not live to finish his studies of the endowments of Mikythos and Stesileos: "Études d'épigraphie délienne," BCH 68-69 (1944-45), p. 271-283; for the latter see his unpublished Études, p. 425-525. BRINGMANN, Schenkungen, nos. 142[E], 151[E], 182[E], with vol. 2.1, Geben und Nehmen: Monarchische Wohltätigkeit und Selbstdarstellung im Zeitalter des Hellenismus, Berlin, 2000, p. 84-87. Also useful, VIAL, Délos indépendante, p.104-105, 205-207, 214, 380-381; R. BOGAERT, Banques et banquiers dans les cité grecques, Leiden, 1968, p. 153-161.

3. And a large share of the Delian festival calendar: BRUNEAU, Recherches, p. 670-671, Index III Fêtes.

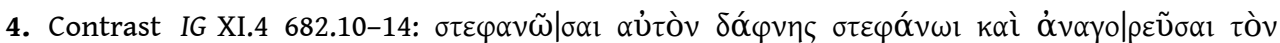

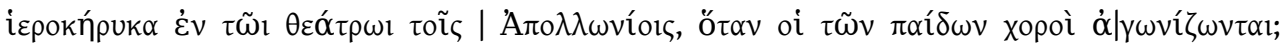

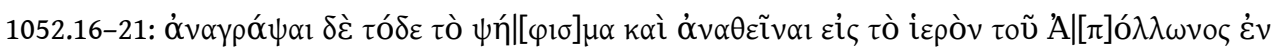

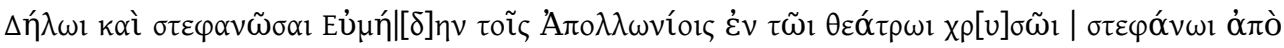

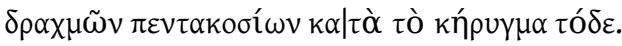

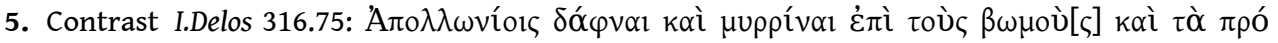

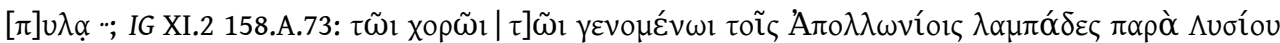

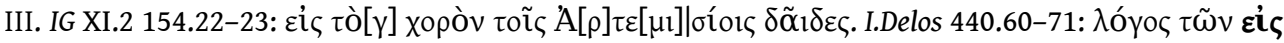

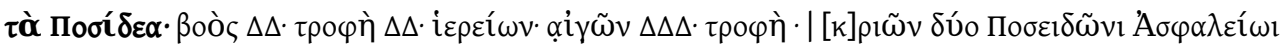

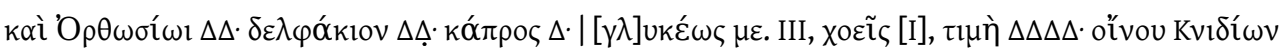

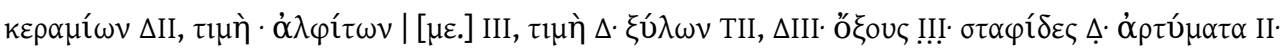

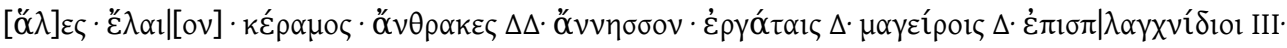

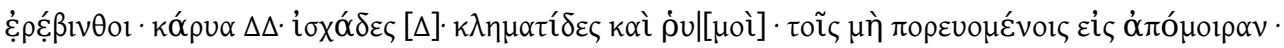

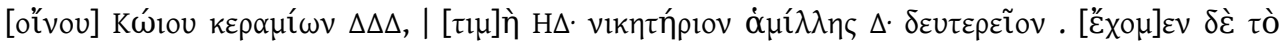

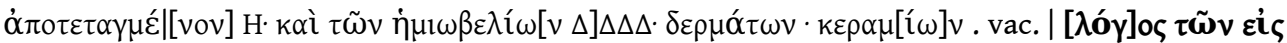

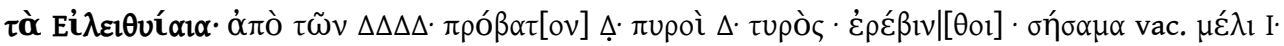

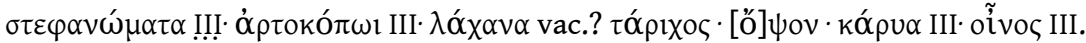

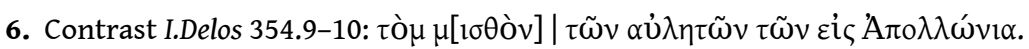

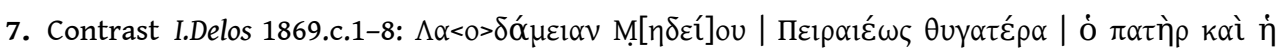

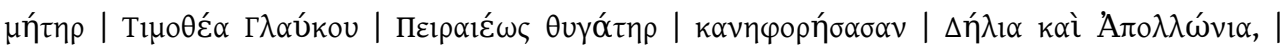

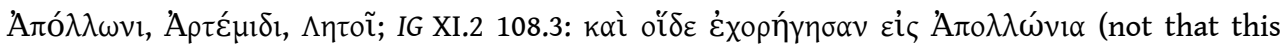
specific ministration was necessary in the case of endowed ritual).

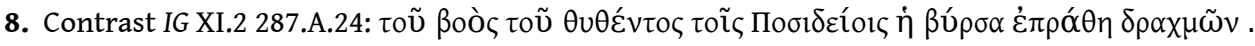

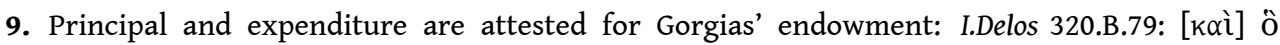

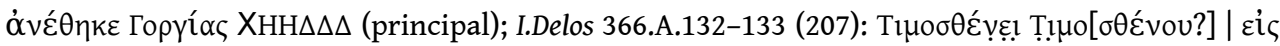


Гopүíદı $\{1\} \mathrm{H} \Delta \Delta$ (interest); also Echenike's: IG XI.2 287.A.122-123 (250) [Bruneau, Recherches, 343]:

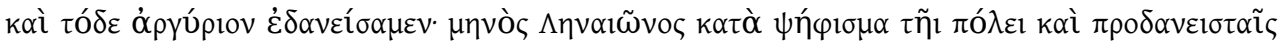

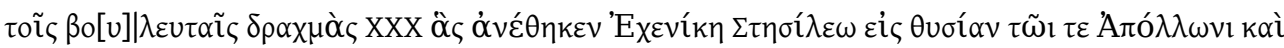

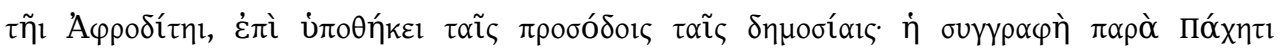

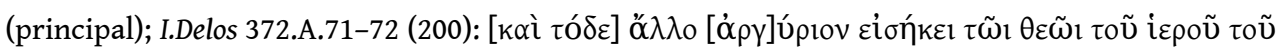

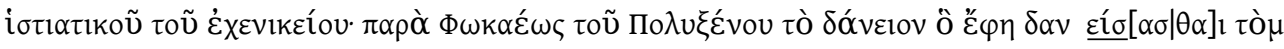

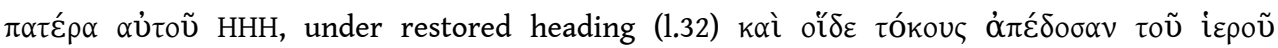

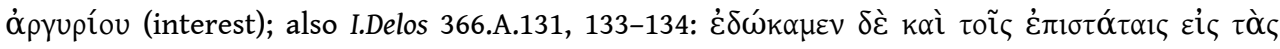

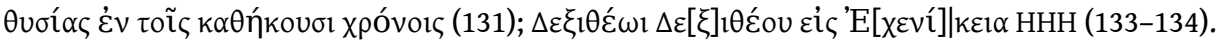

10. For which see still LaUm, Stiftungen.

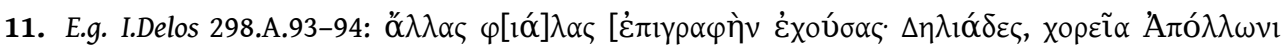

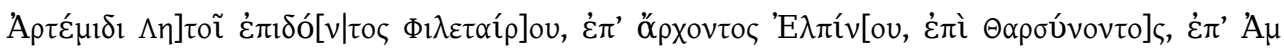

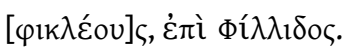

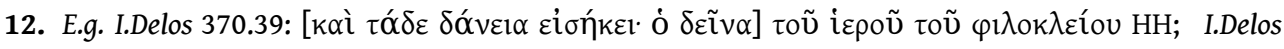

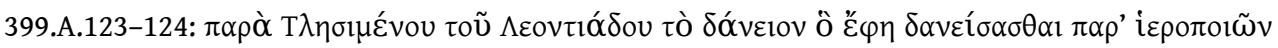

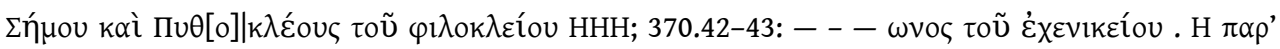

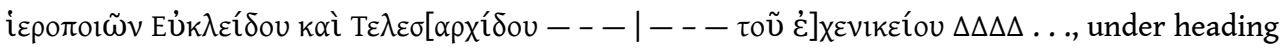

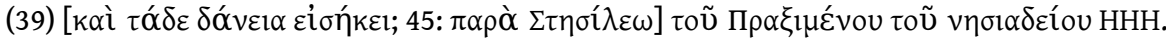

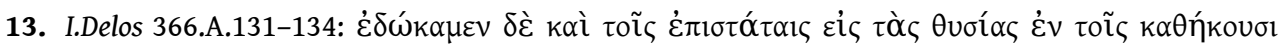

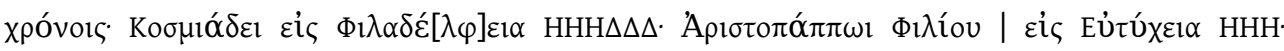

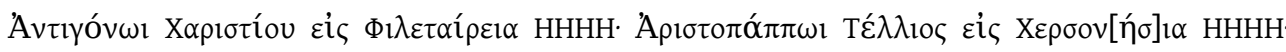

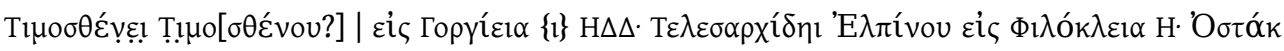

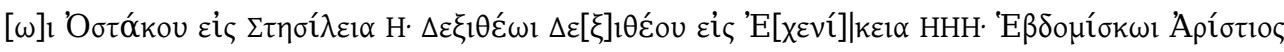

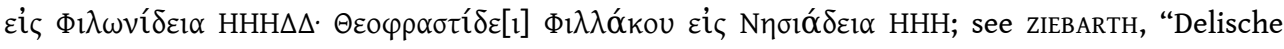
Stiftungen," p. 433.

14. On the prytanikon / hestiatikon: F. DURRBACH, E. SCHULHof, "Fouilles de Délos," BCH 30 (1910), p.122-186, p.160-165; BRUNEAU, Recherches p.442-443; VIAL, Délos indépendante, p. 205-207; TRÉHEUX, Études p. 206 n. 3, 466.

15. On the two female founders on Delos, as well as others elsewhere, see E. STAVRIANopoulou, "Gruppenbild mit Dame". Untersuchungen zur rechtlichen und sozialen Stellung der Frau auf den Kykladen im Hellenismus und in der römischen Kaiserzeit, Stuttgart, 2006, p. 228-249.

16. BRUNEAU, Recherches, p. 448-449; TRÉHEUX, BCH 68-69 (1944-45), p. 278-279.

17. BRUNEAU, Recherches, p. 519-523.

18. IG XI.2 287.A.122-123; BRUNEAU, Recherches, p. 343. Also in 250, Echenike dedicated a phiale weighing 120 drachmas, which seems not to have been paid for from the endowment: IG XI.2

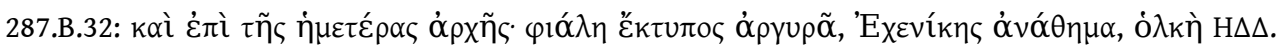

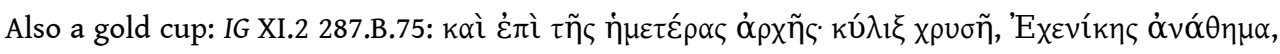
$\dot{\mathrm{o}} \lambda \kappa \eta े$; I.Delos 313.frab.34; this kylix seems to have been the same as the hedupotis also credited to

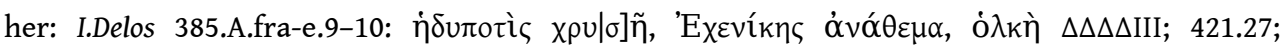
439.fra.6-7; 442.B.7; 455.B.fra.7; 461.B.fra.9; 465.frd.8; 469bis.8.

19. Outlay in 207 BC was 870 drachmas: I.Delos 366.A.134. Philonis' other dedications included a thymiaterion that weighed more than 1100 drachmas: I.Delos 1450.A.162-163: $\theta u \mu 1 \alpha \tau \eta ́ p i o v$

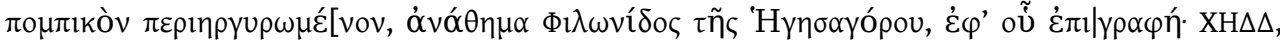

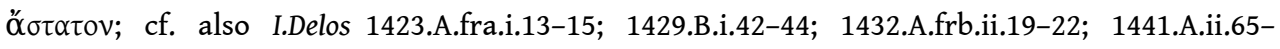
66;1449.A.frab.ii.143-145. Also, an array of other valuable vessels: I.Delos 1432.A.frb.ii.24-29; 1441.A.ii.69-73; 1441.A.ii.117-118; 1449.A.frab.ii.147-150; 1450.A.164-166; 1450.A.186; 1462.2-5.

20. Nesiades: IG XI.2 289.16-18; The earliest attested phiale from Gorgias' endowment was

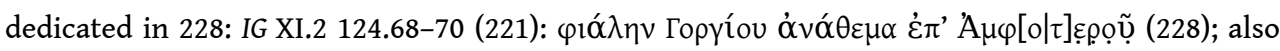


122.63-65 (224) restored. The phialion that he dedicated in 230 was unrelated to the endowment:

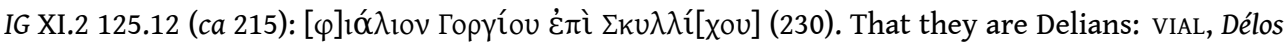
indépendante, p. 381.

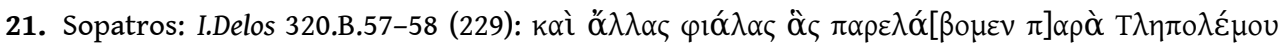

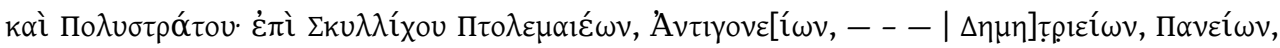

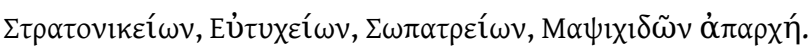

22. The earliest attested phiale was dedicated in 251. I.Delos 398.A.90-91 (240); 313.frab.71 (235/4? ); 314.B.78-79 (after 235/4) restored; 320.B.36-37 (229) restored. Patronym and ethnic preserved:

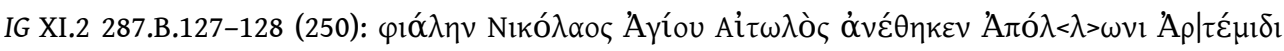

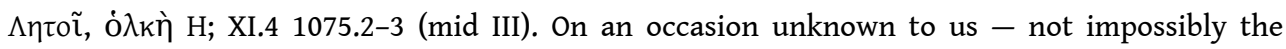
creation of the endowment itself - he was honored for his "piety toward the sanctuary and

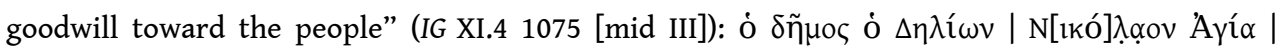

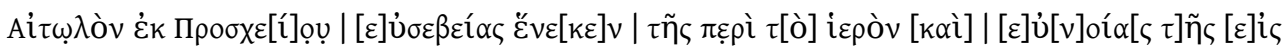
[ $\tau$ òv $\delta \tilde{\eta} \mu$ ]ov. E. WILL, Histoire politique du monde hellénistique 323-30 av. J.-C. (2 ${ }^{\text {nd }}$ ed., Nancy 1979-82) vol. I, p. 327, notes that Nikolaos "fonde une fête à son nom, les Nikolaieia, du même type que les Ptolemaieia ou que les Antigoneia!" This is true, but it might be more apt to say that both he and the kings were following the example of Delian locals.

23. BRUNEAU, Recherches, p. 530 n. 4, 658. ZIEBARTH, "Delische Stiftungen," p. 430, thought him a banker; V. GABRIELSEN, "Banking and Credit Operations in the Hellenistic Times," in Z.H. ARCHIBALD et al. (eds.), Making, Moving and Managing: The New World of Ancient Economies, 323-31 BC, Oxford, 2005, p. 136-164, 155, dubs him a "specialist in Delian sea finance"; we know only that he resided on Delos, "collaborat[ed] in just fashion with those who sail the sea," and was honored for

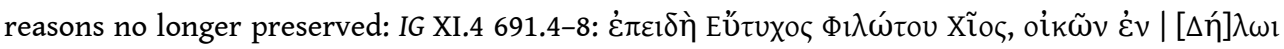

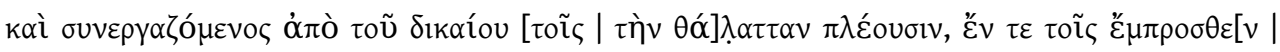

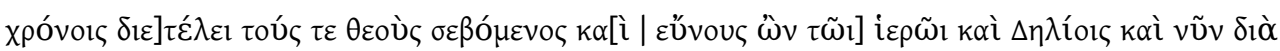

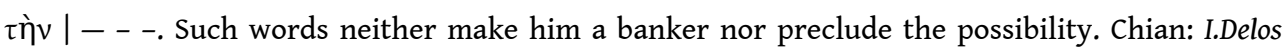

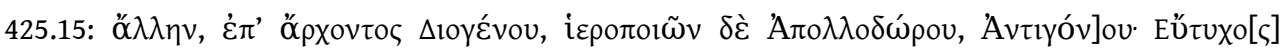

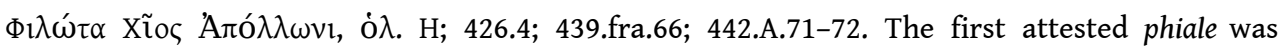
generated in 230 and recorded in 229.

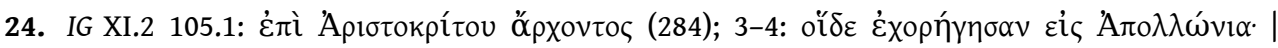

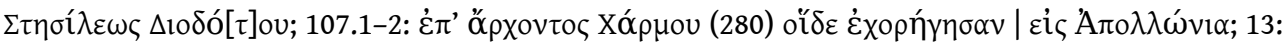

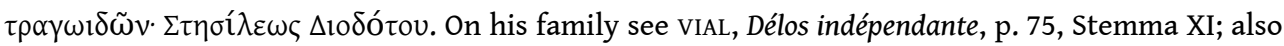
TRÉHEUX, Études, p. 429-433.

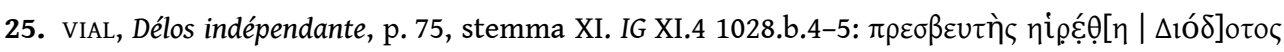

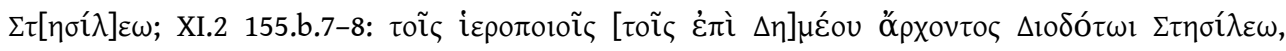

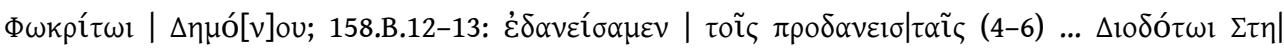

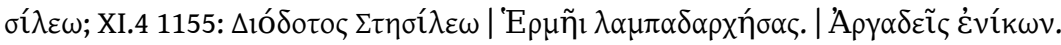

26. C. DURVYE, “Aphrodite à Délos : culte privé et public à l'époque hellénistique," REG 119 (2006), p. 83-113, esp. 94-97. BRUNEAU, Recherches, p. 336.

27. E.g. BRUNEAU, Recherches, p. 337. R. HAMILTON, Treasure Map: A Guide to the Delian Inventories, Ann Arbor, 2000, p. 187-189, 189: "It is virtually certain that [Stesileos] constructed the sanctuary as well as providing the cult image." Guide de Délos ${ }^{4}$, no. 88 p. 261: "il fut consacré par Stésiléos." Recent excavations support a construction date in the late fourth century: C. DURVYE, "Délos. L'Aphrodision : rapport sur les fouilles de juillet 2008," BCH 133 (2009), p. 597-608, 602-605; also that the area was not completely undeveloped at the time of construction: p. 605-607. The oikos immediately to the west of the temple, on the other hand, appears to have been built at the same time: DURVYE, REG 119 (2006), p. 96-97. C. DURVYE, "Recherches récentes à Délos : l'Aphrodision de Stèsileôs," RA (2009), p. 198-207, 200, conjectures that perhaps it stored phialai generated by Stesileos' endowment or served as a banquet hall. 
28. Guide de Délos ${ }^{4}$, no. 88. See especially DURVYE, RA (2009), p. 198-207; BCH 133 (2009), p. 597-608; "Délos. L'Aphrodision : étude du matériel mis au jour en 2005-2006," BCH 132 (2008), p. 803-806; "Délos. L'Aphrodision : fouilles dans la partie orientale du sanctuaire," BCH 130 (2006), p. 728-741; still highly useful is BRUNEAU, Recherches, p. 334-341.

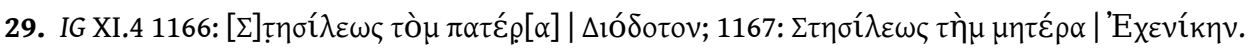

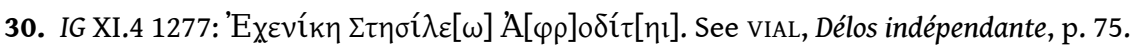

31. C. DURVYE, "Évolution fonctionelle d'une divinité à l'échelle locale : les offrandes à l'Aphrodite de Stèsileôs à Délos," Kernos Suppl. 23 (2009), p. 149-167, 156-160. By the time Athens returned to control of the island, patronage of the little temple seems to have declined somewhat and dedications seem more modest: DURVYE, in Kernos Suppl. 23 p. 160-162. And yet this is also the period in which the sanctuary was apparently expanded, with the addition of a cluster of oikoi adjacent to the temple, to the east. DURVYE, RA (2009), p. 202-205. The designation, 'oikoi,' is

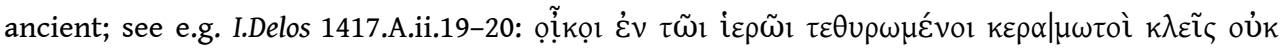

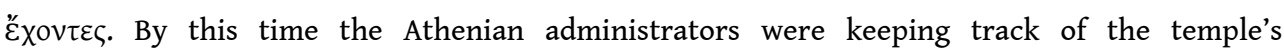
dedications. I.Delos 1412.28-35; 1417.A.ii.1-21, the fullest accounting; 1423.B.a.ii.17-23; 1426.B.ii.1-22; 1442.B.30-35; 1443.B.ii.91-101.

32. J. MA, Statues and Cities: Honorific Portraits and Civic Identity in the Hellenistic World, Oxford, 2013, p. 229.

33. Guide de Délos ${ }^{4}$, no. 91; BRUNEAU, Recherches p. 459-461. It may also call to mind the Mouseion established by Epikteta, on Thera, about a century later, a private sanctuary established by and for a prominent family and bespeaking its own particular piety: IG XII.3 330 [A. WITTENBURG, Il testamento di Epikteta, Trieste, 1990; LAUM, Stiftungen, 43].

34. DURVYE, RA (2009), p. 199-202.

35. GABRIELSEN, l.c. (n. 23), p. 153-154, emphasizes the family's engagement in business: "Diodotos, one of the seven prodaneistai in $282 \mathrm{BC}$, was the son of Stesileos, who in 302 had established the foundation Stesileia, and the brother of Echenike, who in 250 set up the foundation Echenikeia; four years earlier (286), he himself had served the sanctuary as hieropoios. ... These individuals and indeed the entire ensemble of Delian prodaneistai -fall squarely into the larger group of portfolio-holding entrepreneurs, who engaged in moneylending either independently or as energetic, profit-making sub-lenders standing amidst chains of credit. In the period of independence, temple, city and wealthy Delians had formed a smoothly working credit coalition."

36. See, however, the qualification offered by MA, o.c. (n. 32), p. 233-234: "The monuments set up by Stesileos on Delos - two family statues, and a temple - sound like a grand statement, but it is important to realize that they were set up in an isolated site on the edge of the main area of the shrine: segmented off from the epiphanestatoi topoi reserved for dedications and the very rare public honorific statues, and excentric. During the period of Delian independennce, most private honorific families in the late third and second centuries BC crowded within the dromos ..., in a series that hinted at a form of organization, public control, and family consent to collaborate with the public. The case of Stesileos suggests that the elitist analysis cannot be pushed too far, because of the diversity and fragmentation of social space in the Hellenistic cities: what was the audience of the family monuments? Could the habit of family statues have been an elite passetemps, part of an incoherent social landscape which combined signs of political institutions and discourses as well as private, 'anthropological' values and interests? Could the practice have been part of a complex and evolving dialectical relationship between the community and the elite which it helped constitute?" м. Ісотт, Space and Society in the Greek and Roman Worlds, Cambridge, 2013, p. 60, suggests that the site is part of increased development, heavily religious, in a transit zone. 
37. E.g. W.W. TARN, "The Battles of Andros and Cos," JHS 29 (1909), p. 264-285, 271-274; K. BURASELIS, Das hellenistische Makedonien und die Ägäis: Forschungen zur Politik des Kassandros und der drei ersten Antigoniden (Antigonos Monopthalmos, Demetrios Poliorketes und Antigonos Gonatas) im Ägäischen Meer und in Westkleinasien [= MünchBeitr 73], Munich, 1982, p. 146-151; G. REGER, "The Date of the Battle of Kos," AJAH 10 (1985) [1993], p. 155-177, 158-159; id., "The political history of the Kyklades: 260-200 B.C.," Historia 43 (1994), p. 32-69, notes (p. 54 n. 92) that the "several festivals" of Antigonos "have been the subject of endless discussion, usually attached to the date (s) of the battles of Kos or Andros and the reality (or illusion) of an Antigonid hegemony over the islands after c. 250 B.C."; c. CHAMPIon, "In Defence of Hellas: The Antigonid Soteria and Paneia at Delos and the Aetolian Soteria at Delphi," AJAH 3/4 (2004/05) [2007], p. 72-88.

38. G. HÖLBL, A History of the Ptolemaic Empire, London/New York, 2001, p. 98.

39. R.M. ERRINGTON, A History of the Hellenistic World 323-30 BC, Malden, 2008, p. 107.

40. J.B. SCHOlten, Politics of Plunder: Aitolians and their Koinon in the Early Hellenistic Era, 279-217 B.C., Berkeley, 2000, p. 99, following BURASELIS, o.c. (n. 37), p. 141-144 and citing (n. 9) the Delian Soteria and Paneia specifically.

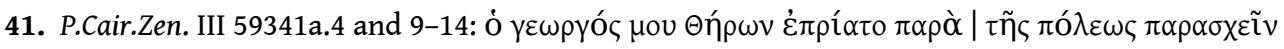

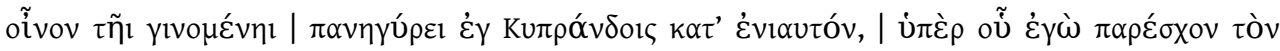

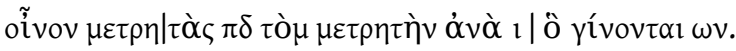

42. On numbers fed by animal sacrifices see F.S. NAIDEN, Smole Signals for the Gods: Ancient Greek Sacrifice from the Archaic through Roman Periods, Oxford, 2013, p. 258-268.

43. As E. BICKERMAN, “Sur les batailles navales de Cos et d'Andros," REA 40 (1938), p. 369-383, 374375, worried long ago: "Il faut fermer les yeux à l'évidence pour estimer que la fondation d'un tel sacrifice par un souverain équivalait nécessairement à une manifestation de sa puissance dans l'Égée. C'était simplement un hommage à Apollon (financièrement assez médiocre), qui marquait, à soi seul, seulement l'existence de bonnes relations entre le donateur et les Déliens et, partant, la puissance protectrice de l'Ile sainte." BRUNEAU, Recherches, p. 579-583, saw some scope for political implications, but fundamentally agreed; similarly, HAMMOND - WALBANK, Macedonia, p. 593 and F.W. WALBANK, JHS 106 (1986), p. 243, at least in the case of The Paneia and Soteria. See also WILL, o.c. (n. 22), p. 232.

44. See the list of new and reorganized civic festivals at A. CHANIOTIS, "Sich selbst feiern? Die städtischen Feste des Hellenismus im Spannungsfeld zwischen Religion und Politik," in P. ZANKER, M. WÖRRLE (eds.), Stadtbild und Bürgerbild im Hellenismus, München, 1995, p. 147-172, 164-168. Festivals named for founders - Delos excepted - represented a small fraction of the considerable growth in new and expanded festal activity. J.D. MIKALSON, Religion in Hellenistic Athens, Berkeley, 1998, p. 212-213, and scarcely another, hesitates over the designation, 'festival': “Though named after the donor, this 'festival' [sc. The Stesileia] and others like it on Delos were to give divine honors to the deities, not to the founders.... This particular type of "festival," named after the donor but intended to honor the deity, perhaps derived from the embassies (theōriai) sent to Delos by cities with sacrifices, choruses, and dedications to honor Apollo. Whatever its origins, it became the format according to which, in the third century, the Ptolemies, Antigonids, and Attalids made their primary contribution to Delian religious life. In Athens, as we have seen, benevolent Hellenistic monarchs might be rewarded with divine honors and large public festivals in their honor. But on Delos these same monarchs received from the Delian state itself no such honors. Rather, the kings or members of their families or staff contributed sums of money, probably rather modest by their standards, and from the interest each year a sacrifice was performed, the Deliades sang, and a vase was made and inscribed to commemorate the event. The celebration was named after the monarch, whether Ptolemaieia, Antigoneia, or Attaleia, but the recipient of the honors was Apollo, not the monarch." 
45. I.Thessaly 52 (III): Leonides of Halikarnassos dedicated a stoa, its rents to be used to fund the eponymous gymnastic competition. IG XII.4 350 (late 2nd cent. BC): a gymnasial calendar from perhaps as much as a century later indicates that The Pythokleia - presumably the very same -

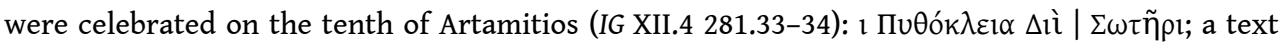
from the mid 2nd century AD mentions a hereditary priest of the Pythokleians, presumably an association that was invested in the cult, perhaps of individuals claiming descent from Pythokles:

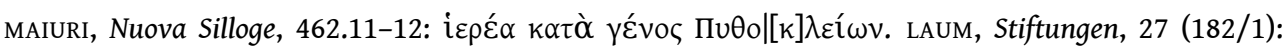
Alkessipos of Kalydon gave 130 gold staters and 22 minas, 30 staters of silver to endow a sacrifice and public feast to Apollo Pythios. DITTENBERGER, Syll. ${ }^{3}$ 672, 671 [LAUM, Stiftungen, 28, 29] (160/59): Attalos II and Eumenes II, apparently at Delphi's request, funded cult to Apollo. Dittenberger (IG VII 43), suggested that the Poseidonios who received endowed sacrifices at Aigosthena (III/II) may have been a local Poseidon or simply a human founder like Alkesippos; but that we cannot know: "Argumentum huius tituli gravissimis dubitationibus obnoxium est." In any case the text does not refer to a festival called The Posidonieia vel sim.

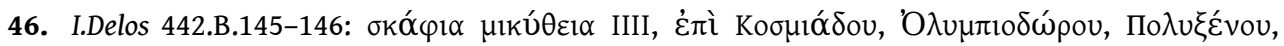

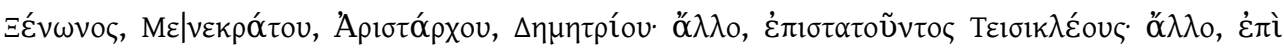

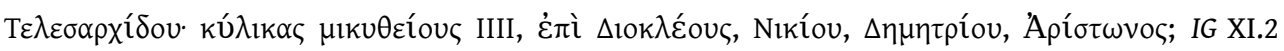

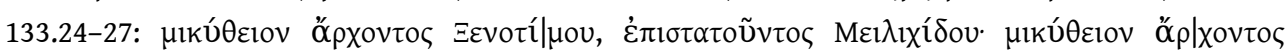

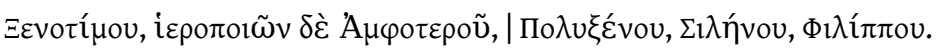

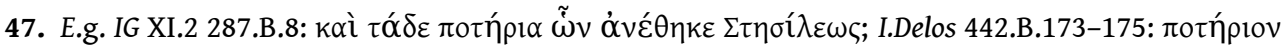

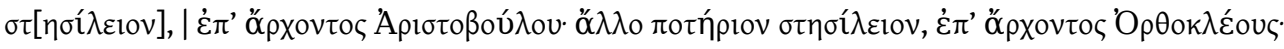

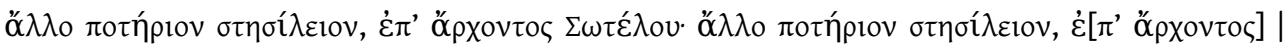

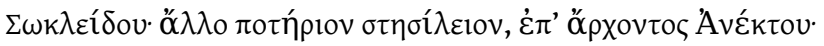

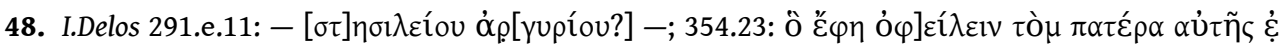

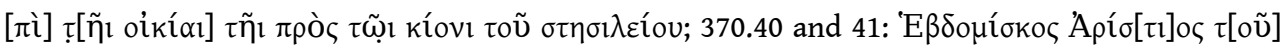

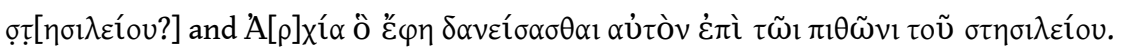

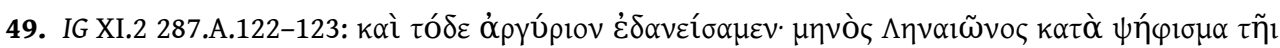

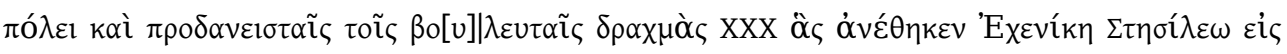

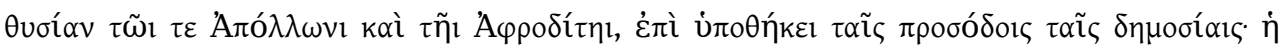

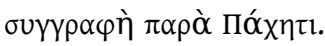

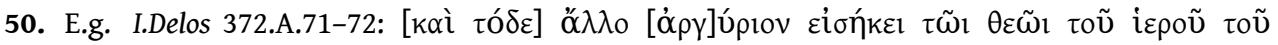

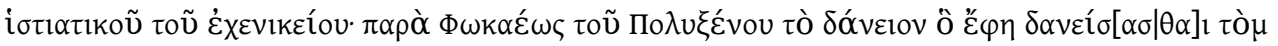

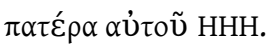

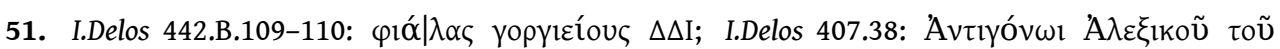
үopүicíou $\mathrm{H}$.

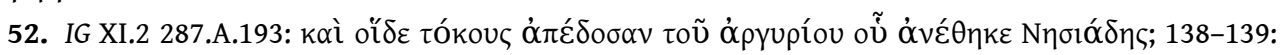

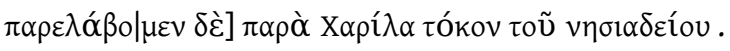

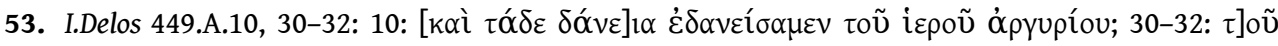

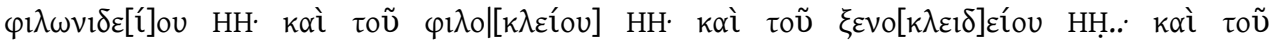

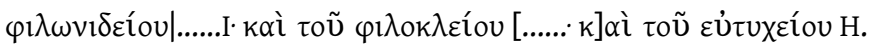

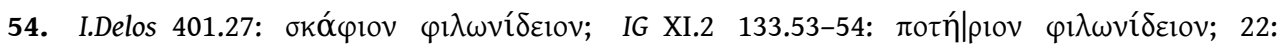
$\varphi \imath \lambda \omega v i ́ \delta \varepsilon 10 v$.

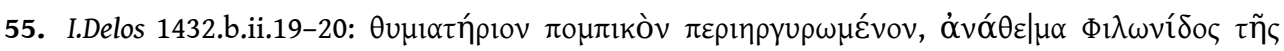

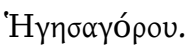

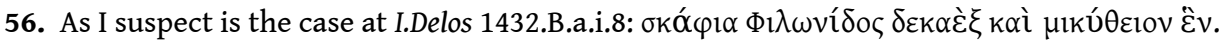

57. E.g. BRUNEAU, Recherches, p. 342-343.

58. VIAL, Délos indépendante, p. 28. 


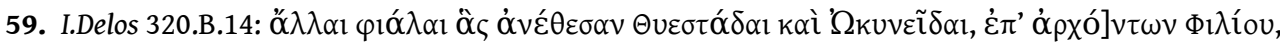

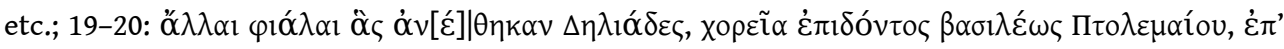

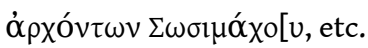

60. L. CRISCUOLO, "Agoni e politica alla corte di Alessandria. Riflessioni su alcuni epigrammi di Posidippo," Chiron 33 (2003), p. 311-333, at 324-326, raises the possibility that the Ptolemaia in which Etearchos of Cyrene was victorious may have been Delian (Poseidippos, Epigr. 76 [Austin-

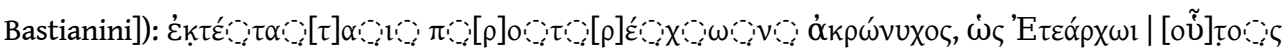

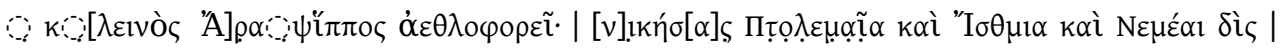

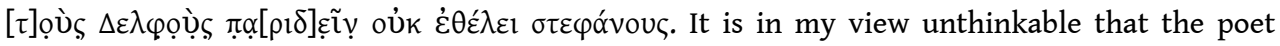
would have put a ritual event funded at a few hundred drachmas per year - even if I am wrong to think that there was no such Delian 'festival'-at the head of a list of victories at the Isthmian, Nemean, and Pythian games. The reference is clearly to the panhellenic Ptolemaia at Alexandria; see e.g. D.J.thompson, "Posidippus, Poet of the Ptolemies," in K. Gutzwiller (ed.), The New Posidippus: A Hellenistic Poetry Book, New York, 2005, p. 269-283, 280.

61. See still: E.F. BRUCK, Totenteil und Seelgerät im griechischen Recht; eine entwicklungsgeschichtliche Untersuchung zum Verhältnis von Recht und Religion mit Beitrâgen zur Geschichte des Eigentums und des Erbrechts, München, 1926; id., "Les facteurs moteurs de l'origine et du développement des fondations grecques et romaines," RIDA 2 (1955), p.159-166. W. KAMPS, "Les origines de la fondation cultuelle dans la Grèce ancienne," in J. PIRENNE (ed.), Archives d'histoire du droit oriental, Bruxelles/Paris, 1937, vol. I p.145-179. More recently A. WITTENBURG, "Grande familles et associations cultuelles à l'époque hellénistique," Ktema 23 (1998), p. 451-455; S.B. POMEROY, "Family Values: The Uses of the Past," in P. BILDE et al. (eds.), Conventional Values of the Hellenistic Greeks [= Studies in Hellenistic Civilization 8], Aarhus, 1997, p. 204-219. IG XII.3 329 [LAUM, Stiftungen, 44]; IG IV IV $^{2} 1236$ [LAUM, Stiftungen, 57; IG IV 840]; IG IV 841.14-24 [LAUM, Stiftungen, 58]; here, the city played a key role, appointing two overseers to lend the money, let the land, collect both interest and rents, perform the sacrifice, nominate auditors, and render accounts of their activities. Public though the setting was, this was family ritual: KAMPS, ibid., p. 171. F. GHERCHANOC, L'Oikos en fête. Célébrations familiales et sociabilité en Grèce ancienne, Paris, 2012, p. 159-168

62. IG XII.4 348.86-115.

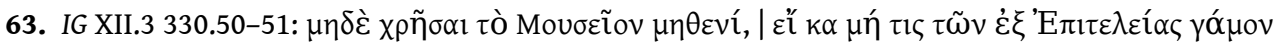
$\pi$ זọn.

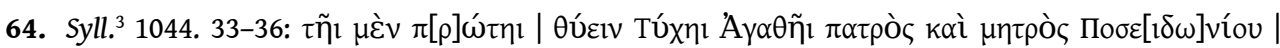

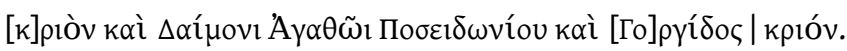

65. IG XII.7 515. The Delphic Attaleia, whose audience was the modest community of gymnasium attendees, could draw on but 200 drachmas (3000 at interest of $1 / 15^{\text {th }}$ ) for "sacrifices and honors"

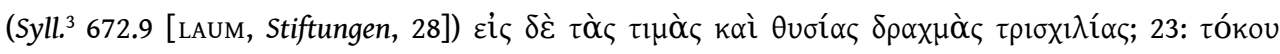

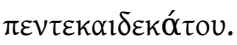

66. When Euagis daughter of Kleusthenes endowed cult for Asklepios, among others, she may have named the cult after her father. The enabling document is very poorly preserved. P.M. FRASER, G.E. BEAN, The Rhodian Peraea and islands, Oxford, 1954, p. 16, saw a possible reference to a

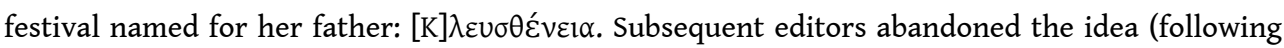

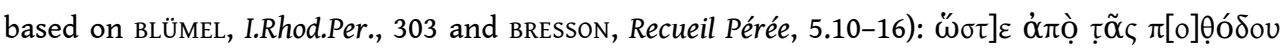

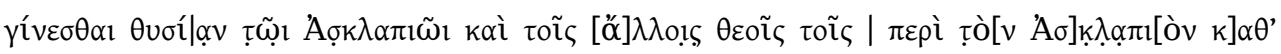

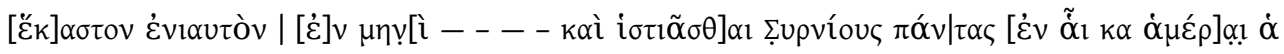

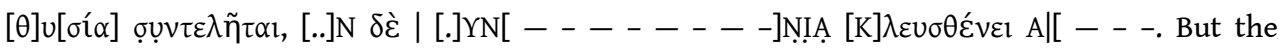
orphaned letter at line-end (15) is worrisome and the condition expressed at lines 14-15 might

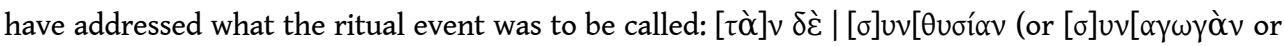

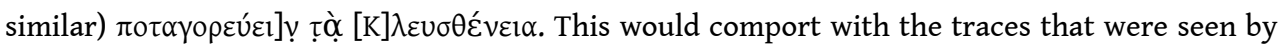
Blümel, understood by Bresson, and are - just barely - visible in the photograph of the squeeze 
printed by Fraser and Bean. Thus, the decree would have begun: since Euagis gave money and real-estate (3-9), "so that from the income there may be a sacrifice to Asklepios and the other gods around the Asklepieion each year, in the month of ... and so that all the Syrnians may feast on whatever day the sacrifice is held, and so that they may call the sacrifice the Kleustheneia..."

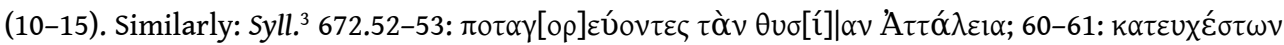

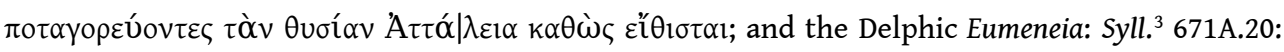

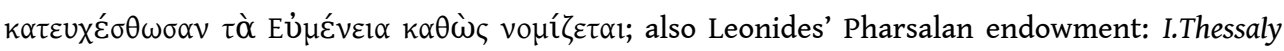

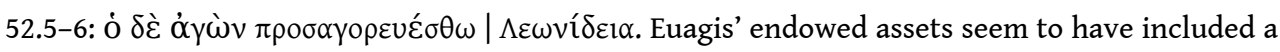

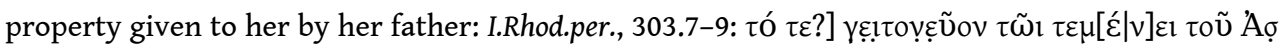

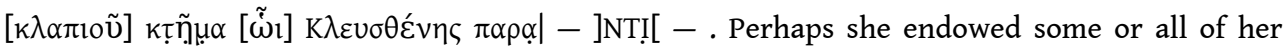
dowry upon his death? We cannot know. But whatever the case, she, like Diomedon or Epikteta or Poseidonios, did not found cult named after herself; if anything, honored though she was, her actions sought to confer honor not on herself but on her father, whose death may have been the occasion of the endowment's creation.

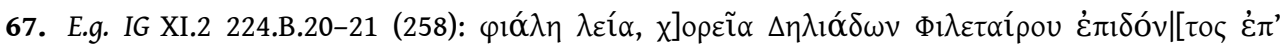

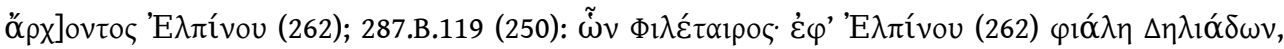

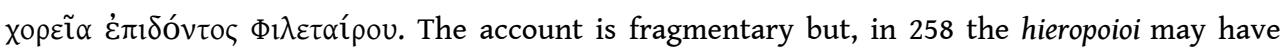

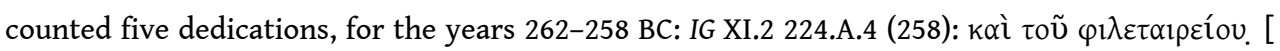
- .

68. R.B. MCSHANE, The Foreign Policy of the Attalids of Pergamum, Urbana, 1964, p. 40, also 43, where it is suggested without argument that the Delian Philetaireia "may better be dated well before 263;" BRUNEAU, Recherches, p. 571: "Philétairos mourut la même année 263, mais cela n'empêche pas qu'il ait pu fonder lui-même la fête;" foundation by Philetairos is implicit in E.V. HANSEN, The Attalids of Pergamon, $2^{\text {nd }}$ edition, London, 1971, p. 19, but cf. n. 27; H.-J. SCHALLES, Untersuchungen zur Kulturpolitik der pergamenischen Herrscher im dritten Jahrhundert vor Christus $[=$ Istanbuler Forschungen 36], Tübingen, 1985, p. 38: "Kurz vor dem Tode des Philetairos im Jahr 263 v.Chr. wurden noch von ihm selbst im Apollonheiligtum von Delos die Philetaireia eingerichtet;" BRINGMANN, Schenkungen, 182[E] p. 226, dates the endowment "nach 263 v. Chr." but observes, "Die Philetaireia wurden im Jahr 263 gestiftet; in diesem Jahr starb Philetairos, was aber nicht heißen muß, daß das Fest nicht mehr von ihm selbst gestiftet worden ist." See already T. HOMOLLE, Les archives de l'intendance sacrée à Délos (315-166 av. J.-C.), Paris, 1887, p. 61.

69. E.g. W.A. LAIDlaW, A History of Delos, London, 1933, p. 106; ROSTOVTZEFF, SEHHW III p. 1448 n. 322; R.E. ALLEN, The Attalid Kingdom: A Constitutional History, Oxford, 1983, p. 22 n. 46.

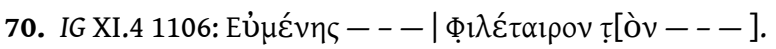

71. In 240 six phialai were attested, so that the endowment's creation must have been in 246 and

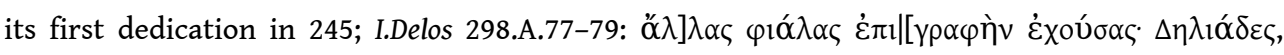

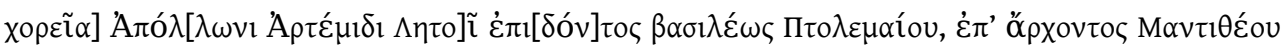

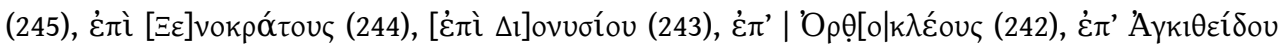

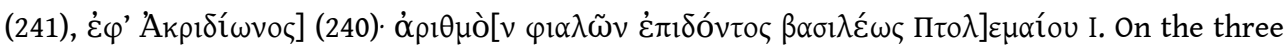
Ptolemaic endowments see Bruneau, Recherches 519-523.

72. E.g. W.W. TARN, Antigonos Gonatas, Oxford, 1913, p. 376: "[O]ne of his first acts had been to see that a foundation to celebrate his accession was made at Delos."

73. IG XI.2 287.B.124; I.Delos 298.A.89-90; 313.a.69-70; 314.B.76-77; 320.B.34-36; 338.Bc.45-48.

74. BRUNEAU, Recherches, p. 561-562; SCHULHOF, BCH 32 (1908), p. 106. P.M. FRASER, C.H. ROBERTS, CdÉ 24 (1949), p. 292 n. 4 suggested that the honorand was the daughter of Antiochos I and wife of Demetrios II but, as HAMMOND - WALBANK, Macedonia, p. 598, n. 6, observed, she was called basilissa in the Delian accounts (e.g. IG XI.2 287.B.124) and Demetrios II was not king until 239. 
75. Plut., Demetr., 31, 3-4; 38, 1-9; 53, 4; on her transfer from father to son: Plut., Demetr., 38, 1-9; App., Syr., 59-61; K. BRODERSEN, "Der Liebeskranke Königssohn und die Seleukidische Herrschaftsauffassung," Athenaeum 63 (1982), p. 459-469.

76. С. НАВІСНТ, Athènes hellénistique. Histoire de la cité d'Alexandre le Grand à Marc Antoine, transl. M. and D. Knoepfler, Paris, 2000, p. 165 is cautious, as is J.J. GABBERT, Antigonus II Gonatas: A Political Biography (New York 1997), p. 52-53; 255: HAMMOND - WALBANK, Macedonia, p. 595-599; BURASELIS, o.c. (n. 37), p. 146-151; earlier: REGER, AJAH 10 (1985) [1993] p. 155-177; id., Historia 43 (1994), p. $40-$ 41.

77. K.J. BELOCH, Griechische Geschichte, Berlin/Leipzig, 1927 vol. IV.2, p. 199-200; BRUNEAU, Recherches, p. 561-562; HAMMOND - WALBANK, Macedonia, p. 598; REGER, AJAH 10 (1985) [1993] p. 159; CARNEY, Women and Monarchy, p. 171.

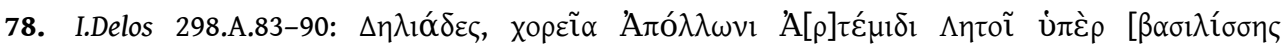

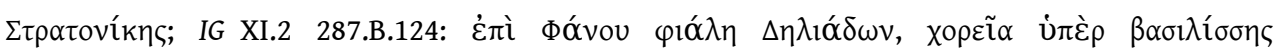

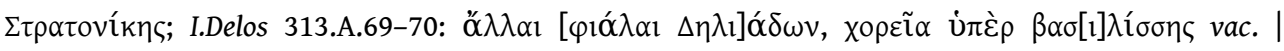

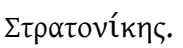

79. J. SEIBERT, Historische Beiträge zu den dynastischen Verbindungen in hellenistischer Zeit [= Historia Einzelschriften, 10], Wiesbaden, 1967, p. 34-36; CARNEY, Women and Monarchy, p. 184-185, with n. 23 p. 310; TARN, o.c. (n. 72), p. 348.

80. The two conflicting accounts of Stratonike's flight from Demetrios to Syria are irreconcilable: Agatharchides, FGrHist 86 F 20a; Just., XXVII, 1, 1-4; cf. HAMMOND - WALBANK, Macedonia, p. 322-323; CARNEY, Women and Monarchy, p. 184-186.

81. CARNEY, Women and Monarchy, p. 182-183.

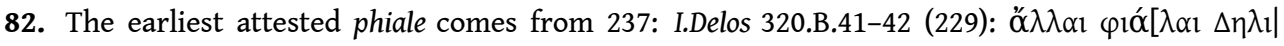

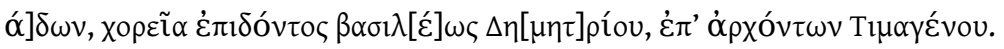

83. REGER, Historia 43 (1994), p. 55, is surely right to see Antigonid dedications on Delos as part of a family tradition: "Demetrios II and Doson's connections with the island need prove nothing more than traditional family interest - no Antigonid since Monophthalmos had failed to make dedications or establish festivals on the island - and predictable piety toward a pan-Hellenic sanctuary."

84. More than half a century before, the league of islanders had created a new festival called the Demetrieia, which was to be celebrated every other year, alternating with the existing Antigoneia. The pair of festivals honored Antigonos Monophthalmos and Demetrios Poliorketes: IG XI.4 1036; cf. BRUNEAU, Recherches, p. 564-568. They were, however, short-lived, fading before the time of Antigonos Gonatas and Demetrios II: BRUNEAU, Recherches, p. 565-566: "[I]l est à peu près sûr qu'après 280 l'institution des Ptolémaieia entraîna la disparition des Antigoneia-Démétrieia." Perhaps, in some small way, Demetrios II thought of his endowment as similarly paired with Antigonos Gonatas', the pair honoring Monophthalmos and Poliorketes as the previous proper festivals had done on grander scale.

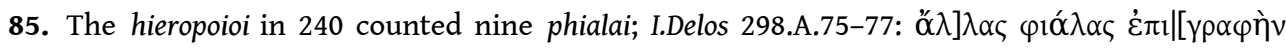

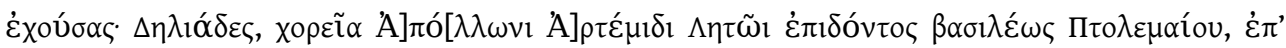

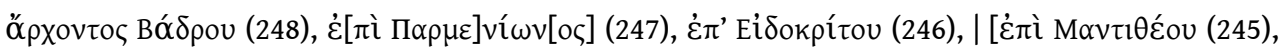

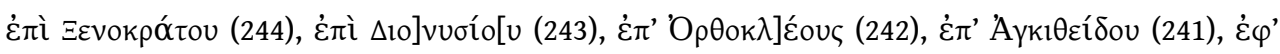

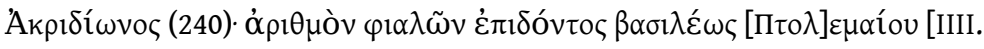

86. TARN, o.c. (n. 72), p. 366: "Ptolemy personally had nothing to do but to emphasize his bloodless victory in the eyes of the world by sending his fleet to Delos, in the year 249, and there establishing in Apollo's honour the foundation which we know as the second Ptolemaieia."

87. REGER, Historia 43 (1994), p. 45.

88. CHAMPION, l.c. (n. 37), p. 75. Also e.g.. HÖLBL, o.c. (n. 38), p. 45. 
89. F. CHAmoux, "Le roi Magas," RHist 216 (1956), p. 18-34; о. мøвкноLм, "Cyrene and Ptolemy I: some Numismatic Comments," Chiron 10 (1980), p.145-159, esp. 145-147; W. HUß, Ägypten in hellenistischer Zeit 332-30 v. Chr., Munich, 2001, p. 202, 333. The principal, and conflicting, sources for the event are: Agatharchides FGrHist 86 F 7; Eusebius, Chron. I, 237-238 (Schoene); Just., Epit. XXVI, 3, 2-8; Paus., I, 6, 8.

90. The earliest attested phiale was dedicated in 267 (archonship of Meilichides); in $250 \mathrm{BC}, 17$ phialai were counted, plus the one dedicated that year: IG XI.2 287.B.112-119, 128.

91. And apparently the same Halikarnassan to whom Delos awarded proxeny: IG XI.4 565.

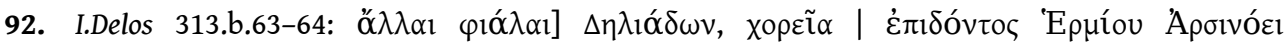

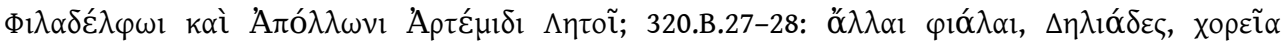

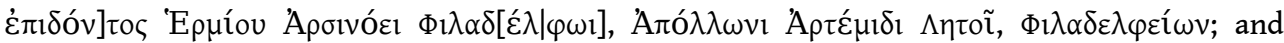

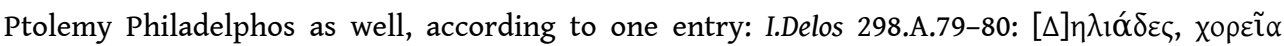

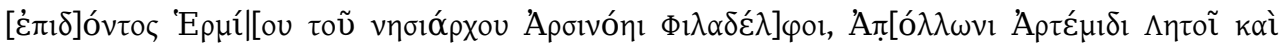
$\beta \alpha \sigma \iota \lambda \varepsilon \tilde{\imath} \Pi \tau 0] \lambda[\varepsilon] \mu \alpha i ́ \omega 1 ; 314 . B .68-69$ restored.

93. B. VAN OPPEN DE RUITER, "The Death of Arsinoe II Philadelphus: The Evidence Reconsidered," ZPE 174 (2010), p.139-150. For continued reservations about the later date, see E.D.CARNEY, Arsinoë of Egypt and Macedon: A Royal Life, Oxford, 2013, p. 100, 104-105.

94. H. HAUBEN, “Arsinoé II et la politique extérieure de l'Égypte,” in E. VAN “T DACK et al. (eds.), Egypt and the Hellenistic World: Proceedings of the International Colloquium, Leuven, 24-26 May 1982 [= Studia Hellenistica, 27], Leuven, 1983, p. 99-127, at 111-114, 124-127. Hermias was not the only Ptolemaic naval officer to be devoted to Arsinoe; also the famous Kallikrates of Samos.

95. L. ROBERT, "Sur un décret d'Ilion et sur un papyrus concernant des cultes royaux," in Essays in Honor of C. Bradford Welles [= AmStudPap, 1], New Haven, 1966, p. 175-211, at 201-202 [= OMS VII, p. 623-632]. See also C. MARquAILle, "The Foreign Policy of Ptolemy II," in P. MCKeCHNIE, P. GUILlaume (eds.), Ptolemy II Philadelphus and his World, Leiden, 2008, p. 39-64, 58-60; A. MEADows, "The Ptolemaic League of Islanders," in K. BURASELIS et al. (eds.), The Ptolemies, The Sea and the Nile: Studies in Waterborne Power, Cambridge, 2013, p. 19-38, 29-30, and H. HAUBEN, "Callicrates of Samos and Patroclus of Macedon," in the same volume, p. 39-65, 47-48, with citations.

96. Date: BRUNEAU, Recherches, p. 521-522. See MEADOWs, l.c. (n. 95), p. 31-32. IG XI.4 1038 preserves a decree of the League of Islanders, proclaiming a crown and honors for Sostratos "at

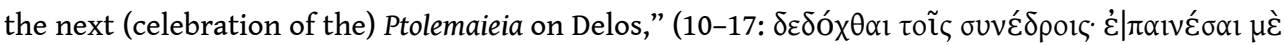

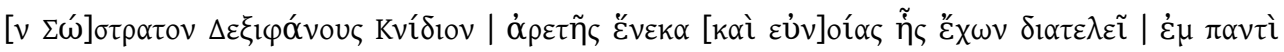

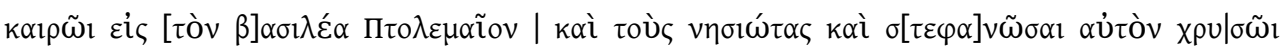

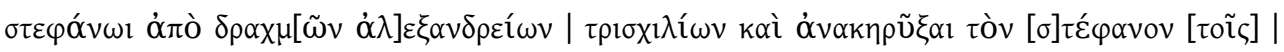

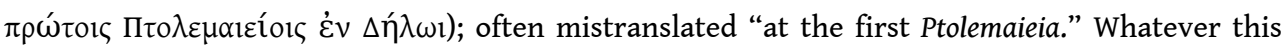
festival entailed, it was a League affair, perhaps referred to in the Nikouria decree, in which the Islanders observe that they have already accorded Soter honors equal to those given to gods (IG

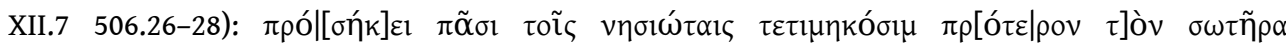

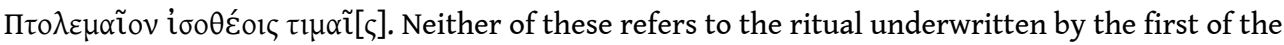
Ptolemaic endowments, contemporary though it was.

97. Memnon FGrHist 434 F 8 (12); Just., XVII, 2, 4-15; XXIV, 1, 1-5, 7.

98. Just., XVII, 2; XXIV, 2-3; S.M. BURSTEIN, “Arsinoe II Philadelphos: A Revisionist View," in W.L.ADAMS and E.N.BORZA (eds.), Philip II, Alexander the Great, and the Macedonian Heritage, Washington, 1982, p. 197-212, at 200 [= S.M. BURSTEIN, Graeco-Africana: Studies in the History of Greek Relations with Egypt and Nubia, New Rochelle, 1995, p. 77-95]. Cf. HUß, o.c. (n. 89),p. 305-306. Precisely when she dedicated there the rotunda to the Great Gods is a vexed issue. The dedication is fragmentary at the very spot where it would tell us the name of her husband (IG XII.8 227):

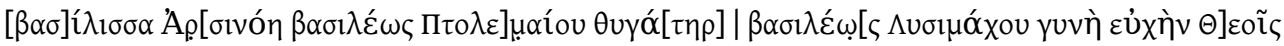

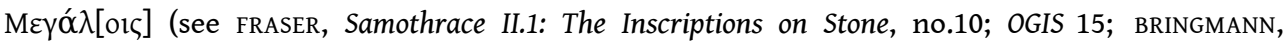


Schenkungen, 236[E]]; re-edited by G. ROUX in J.R. MCCREDIE et al. (eds.), Samothrace VII: The Rotunda of Arsinoe, Princeton, 1992, p. 231-239. If Arsinoe was here the wife of Lysimachos, the dedication must have taken place before his death in 281. See: E.g. S.G. COLE, Theoi Megaloi: The Cult of the Great Gods at Samothrace [= EPRO, 96], Leiden, 1984, p. 22; BURSTEIN, in Philip II..., p. 199; H.S. LUND, Lysimachus: A Study in Early Hellenistic Kingship, London and New York, 1992, p. 168; BRINGMANN, Schenkungen, 236[E] p. 265. A. FRAZER, Samothrace X: The Propylon of Ptolemy II, Princeton, 1990 vol. I p. 143, 227-233; CARNEY, l.c. (n. 93), p. 38. It has also been suggested, however, that she dedicated the structure after she had gone to Egypt and become queen and wife of Ptolemy II: Roux, Samothrace VII, p. 231-239; MEADOWs, l.c. (n. 95), p. 29.

99. H. HAUBEn, Callicrates of Samos: A Contribution to the Study of the Ptolemaic Admiralty; with a Samian Inscription Published in Appendix by Günter Dunst [= Studia Hellenistica, 18], Leuven, 1970, p. 67.

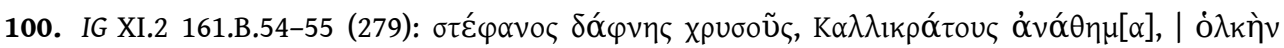

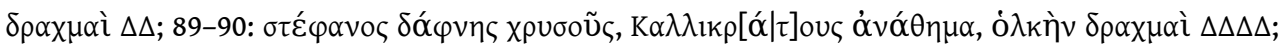
HAUBEN, o.c. (n. 99), p. 26-27. In the following year the hieropoioi inventoried a single crown whose weight was nearly equivalent to the combined weight of the two crowns (IG XI.2 162.B.44):

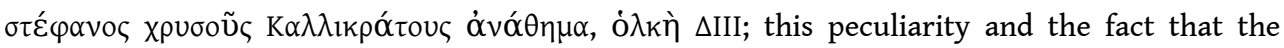
heavier of the two crowns seems to have disappeared from the inventories after 278 (see table at HAUBEN, ibid., p. 26) remain unexplained.

101. HAUBEN, o.c. (n. 99), p. 26-31, proposed a possible visit in 308 (or perhaps 294 or 287) as the probable occasion.

102. For speculation that she might not have returned until perhaps as late as 276 see CARNEY, l.c. (n. 93), p. 63, 66, 70 .

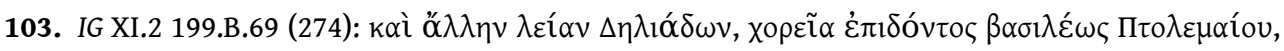

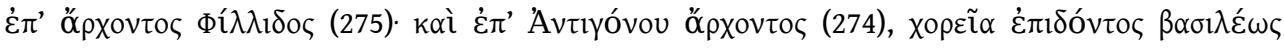

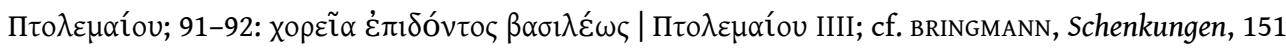
[E].

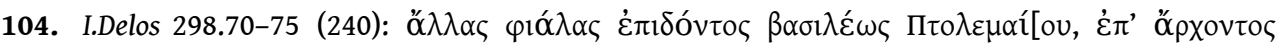

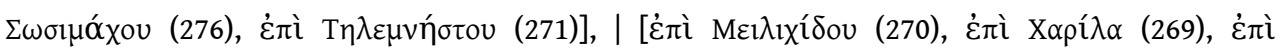

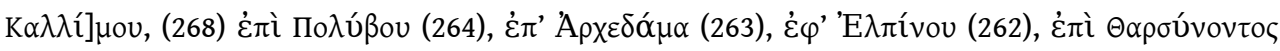

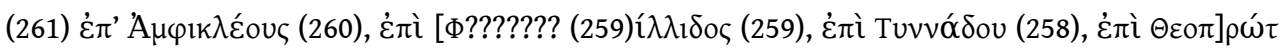

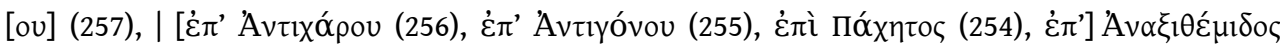

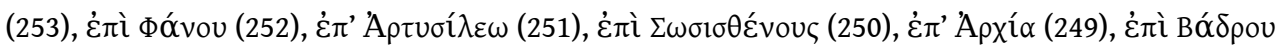

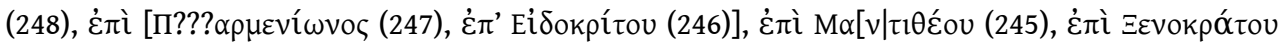

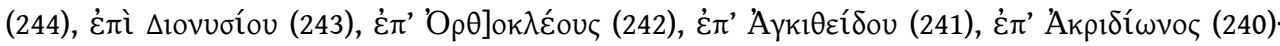

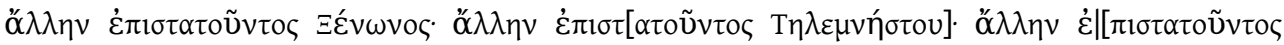

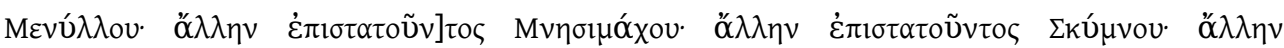

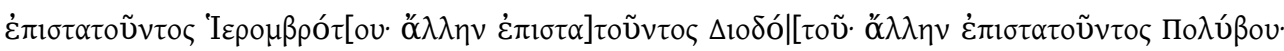

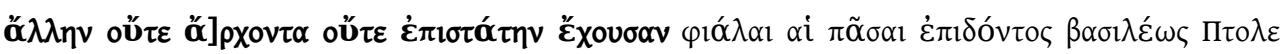

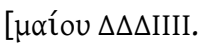

105. BRUNEAU, Recherches, p. 522.

106. Just., Epit. XXIV, 3, 1-8.

107. HUß, o.c. (n. 89), p. 307-308 with n. 22; ca September 279: M. WÖRRLE, "Epigraphische Forschungen zur Geschichte Lykiens II: Ptolemaios II. und Telmessos," Chiron 8 (1978), p. 201-246, at 212-216 [SEG XXVIII 1224]; earlier bibliography at HAUBEN, o.c. (n. 99), p. 35 with n. 3.

108. Whether one thinks she was the driving force behind much Ptolemaic policy or not: BURSTEIN, l.c. (n. 98), p. 197-212 [= Graeco-Africana,p. 77-95]; on the earlier period of her life see E.D. CARNEY, “Arsinoë before she was Philadelphus,” AHB 8 (1994), p. 123-131. 
109. Following L. NERWINSKI, The Foundation Date of the Panhellenic Ptolemaea and Related Problems in Early Ptolemaic Chronology, diss. Duke University, 1981, p. 30-41, 107-108, and passim. A vexed puzzle. See e.g. B. DREYER, Untersuchungen zur Geschichte des spätklassischen Athen (322-ca. 230 v. Chr.) [= Historia, Einzelschr. 137], Stuttgart, 1999, p. 206-207, with citations.

110. BRUNEAU, Recherches, p. 557-561. Earliest dated phialai are dated to 244. I.Delos 298.A.85-86

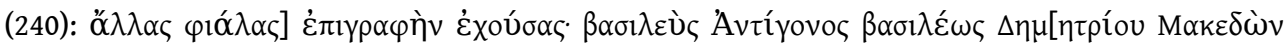

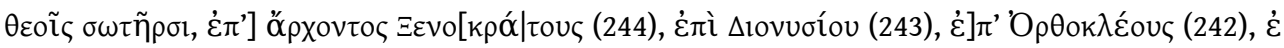

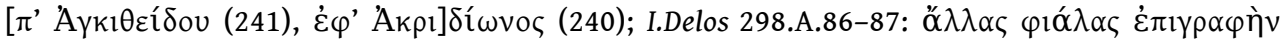

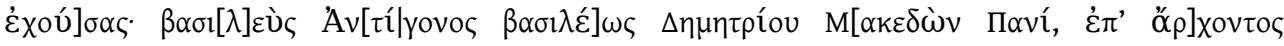

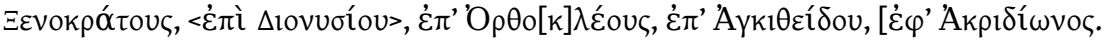

111. REGER, Historia 43 (1994), p. 44-45 ("it is virtually certain that the Paneia and Soteria founded in 245 B.C. by Gonatas commemorated his victory over the Egyptian fleet at Andros"); BURASELIS, o.c. (n. 37), p. 144-145 and in The Hellenistic Polis of Kos, p. 17; CAH VII ${ }^{2}$.1 p. 248-249 (with caution). Apparent in both specialist and general works: e.g. B. HINTZEN-BOLLEN, Herrscherrepräsentation im Hellenismus: Untersuchungen $z u$ Weihgeschenken, Stiftungen und Ehrenmonumenten in den mutterländischen Heiligtümern Delphi, Olympia, Delos und Dodona, Köln, 1992, p. 106-107; HAMMOND - WALBANK, Macedonia, p.587-595, esp. 593-594; R. LANE FOX, “Glorious Servitude...' The Reigns of Antigonos Gonatas and Demetrios II," in R.J. LANE Fox (ed.), Ancient Macedon: Studies in the Archaeology and History of Macedon, 650 BC-300 AD, Leiden, 2011, p. 495-520, 516-517. Cautious: G. NACHTERGAEL, Les Galates en Grèce et les Sôtéria de Delphes. Recherches d'histoire et d'épigraphie hellénistiques, Bruxelles, 1977, p. 180.

112. CHAMPION, l.c. (n. 37), p. 72-88; wiLl, o.c. (n. 22), p. 323.

113. Plut., Arat., 17, 2-5; Polyainos, Strat. IV , 6, 1; quote: CARNEY, Women and Monarchy, p. 188.

114. BRUNEAU, Recherches, p. 559.

115. E.g. I.Delos 366.A.64-89 passim.

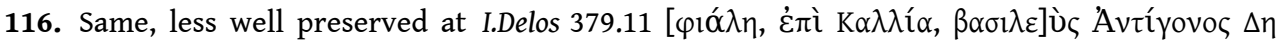

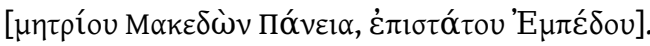

117. And at 379,11 as well.

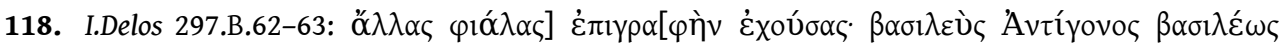

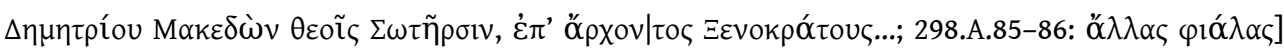

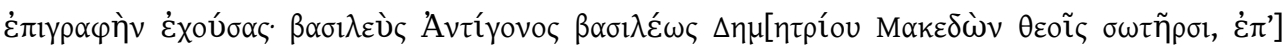

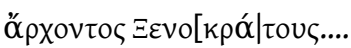

119. Here in the singular agreeing in gender with [ớ $\lambda] \lambda \eta$ ( $\varphi$ เó $\lambda \eta)$, a "phiale of thank-offering;" above, in the plural the "other phialai" were "thank-offerings," in the neuter. See I.Delos 442.B.66 where a single phiale is called a eutycheios (a two-termination feminine nominative), whereas multiples were eutycheia.

120. BRUNEAU, Recherches, p. 559.

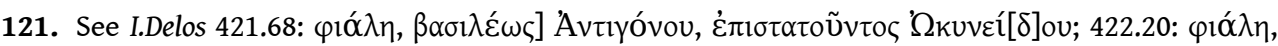

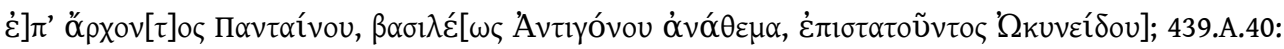

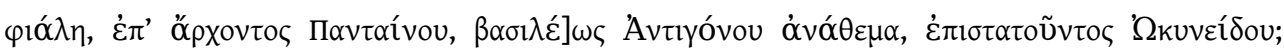

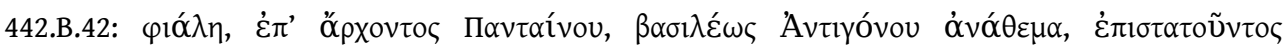

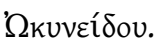

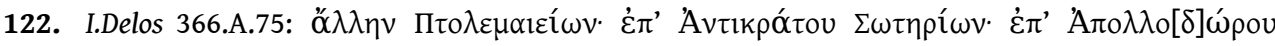

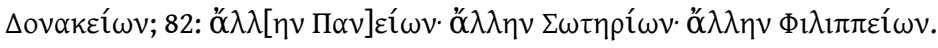

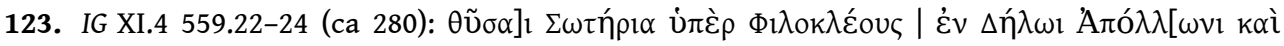

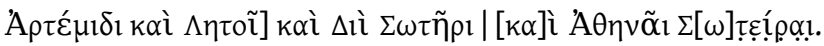

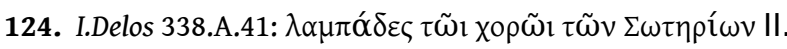


125. A. MOMIGLIANO, P. FRASER, "A New Date for the Battle of Andros? A Discussion," CQ 44 (1950), p. $107-118,115$.

126. Much too much so, I urge, to have been the occasion of special Antigonid coin issues, for which see Panagopoulou, in Hellenistic Economies, p. 263; ead., Antigonos Gonatas: Coinage, Money and the Economy, diss. University College London, 2000, p. 100, 188, 190, 288. I. KRALLI, "The Date and Context of Divine Honours for Antigonos Gonatas - A Suggestion," in O. PALAGIA, S.V. TRACY (eds.), The Macedonians in Athens, 322-229 B.C.: Proceedings of an International Conference held at the University of Athens, May 24-26, 2001, Oxford, 2003, p. 61-66, 66, frames the putative Paneia and Soteria as part of the "context" for Antigonos' receipt of divine honors: "To sum up: In the framework of events suggested above the terminus post quem for the isotheoi timai conferred upon Antigonos Gonatas should be the end of the war against Alexandros ca. 245 or earlier since Alexandros' death occurred ca. 245.... Finally, we could set the divine honours in a broader context. Following the dating suggested above, the divine honours would be more or less contemporaneous with the vase festivals Paneia and Soteria established on Delos by Antigonos Gonatas in 246/5, after his naval victory at Andros over Ptolemy III. In the present state of our evidence we cannot establish a precise chronological sequence, i.e. whether the divine honours postdated or antedated the battle of Andros; in any case, it is notable that the mid-240s witnessed outstanding celebrations of Antigonos Gonatas' glory."

127. REGER, Historia 43 (1994), p. 44.

128. Belief in such extends well beyond specialized scholarship on Delos per se; see e.g. scotT, o.c. (n. 36),p. 59-60; MIKALSON, o.c. (n. 44), p. 212; H. VERSNEL, Coping with the Gods: Wayward Readings in Greek Theology, Leiden, 2011, p. 133, referring to "the temple and cult for Aphrodite at Delos founded by a prominent citizen Stesileos (late 4th c. BC). The cult named after him was continued by his descendants into the second century and was a serious rival of the official Delian Aphrodite cult." STAVRIANOPOUlou, o.c. (n. 15),p. 230-231.

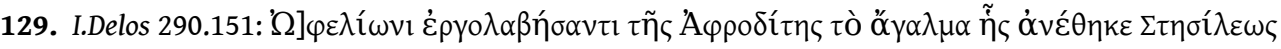

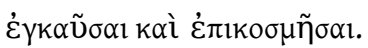

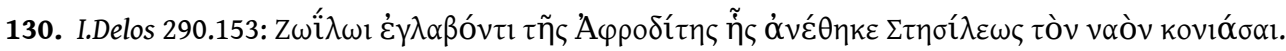

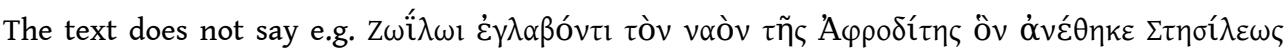

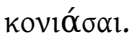

131. DURVYE, RA (2009), p. 200, suggests even that the adjacent oikos (1) may have housed phialai dedicated via the stesileion; but in that case the state would have been using private property to store dedications to a civic deity, which does not seem likely. She suggests also that the building may have been the seat of banquets. If there were such, they were not hosted as part of an endowed eponymous Stesileia.

132. See e.g. J.D. Sosin, "Unwelcome Dedications: Public Law and Private Religion in Hellenistic Laodicea by the Sea," CQ 55 (2005), p. 130-139, 135-139.

133. Even if Stesileos had paid for the temple, for which there is no evidence, he no more owned it after the fact of construction and dedication than, for example, Antigonos Gonatas owned the stoa that he dedicated on Delos; for which: Guide de Délos ${ }^{4}$, no. 29; IG XI.4 1095; BRINGMANN, Schenkungen, $128[\mathrm{~A}]$.

134. The endowment of Agasikles and Nikagora funded sacrifice on an altar set up in front of their images near/in front of the bouleuterion: IG IV 841.23-24 [LAUM, Stiftungen, 58]: $\beta \omega \mu$ òv

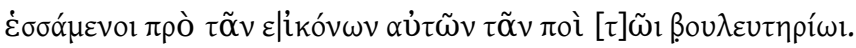

135. If Stesileos was archon in $305 \mathrm{BC}$, he can hardly have been very much younger than 35 . His son Diodotos was already of age in the 280s (VIAL, Délos indépendante, p. 75, stemma XI); if he was born not later than roughly 315 , to a recently wed father, and if Stesileos was roughly 35 at the time, then he will have been born ca 350. This will have put the birth of Stesileos' father Diodotos in the neighborhood of 385. Thus, when Stesileos created the endowment in 302 he will have 
been approaching 50 and his father will have been perhaps in his 80 s, if alive. If Stesileos married around the age of 30 or 40 (so ca. 320-310) and if his daughter Echenike was born within a decade of that date, then she will have been roughly 50-60 when she established her own endowment in $250 \mathrm{BC}$. The occasion of its creation will not have been the death of her father, who, if alive, would have been roughly 100 at the time. If Stesileos at, 30-40, married (ca. 320-310) the woman, at 15-20 years (and so b. ca. 340-325), who would become Echenike's mother, then in 250 Echenike's mother may have been around 75 to 90 years old. These are very crude reckonings, but they suggest (certainly no more) that the deaths of Stesileos' father and Echenike's mother both of whom will have been quite long-lived - just might have been occasions motivating the creation of these endowments

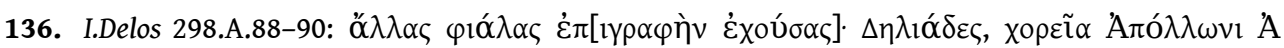

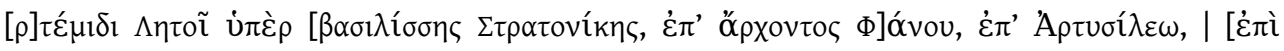

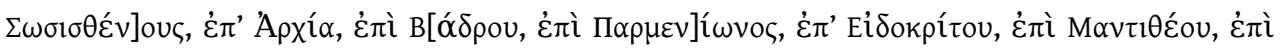

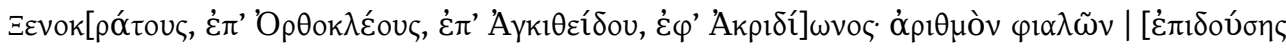
$\beta] \alpha \sigma \lambda \lambda i ́ \sigma \sigma \eta \varsigma, \Sigma \tau \rho \alpha[\tau o v i ́ k \eta \varsigma \Delta \mathrm{II}$.

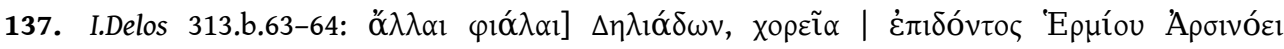

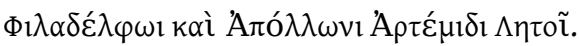

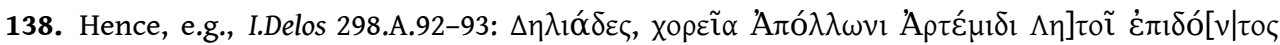

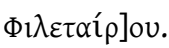

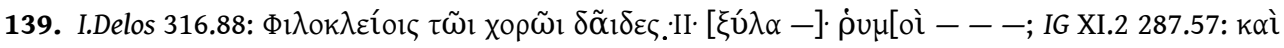

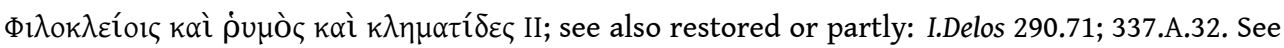

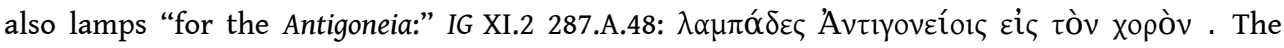

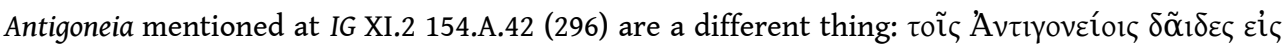

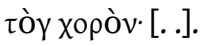

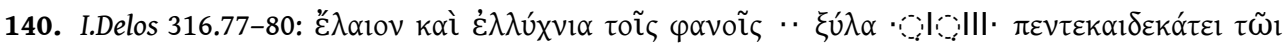

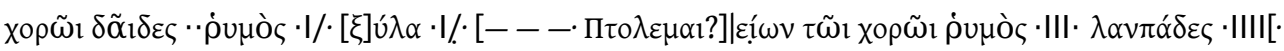

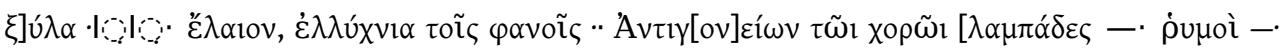

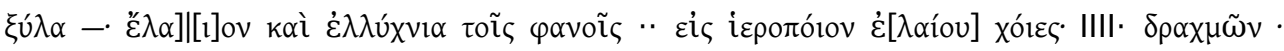

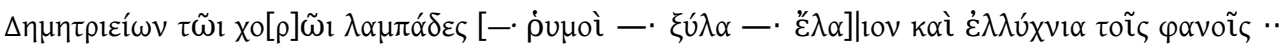

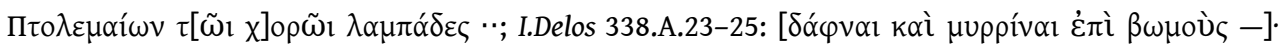

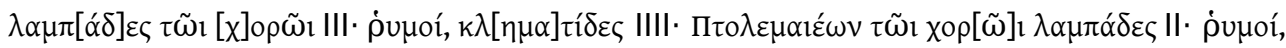

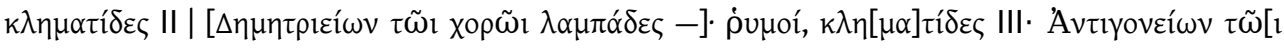

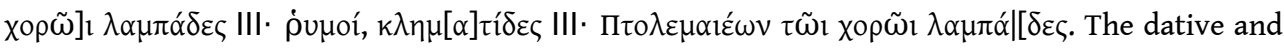
genitive constructions appear in proximity in the same accounts, without any apparent

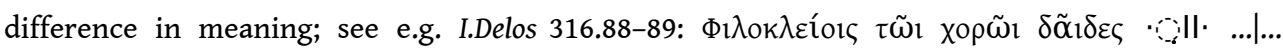

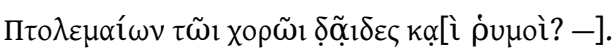

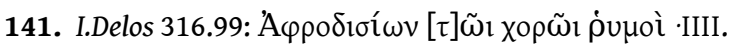

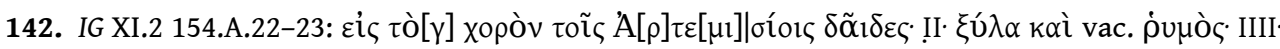

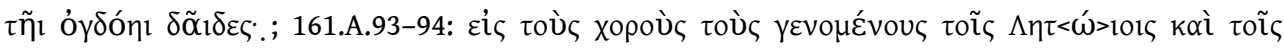

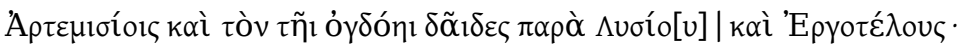

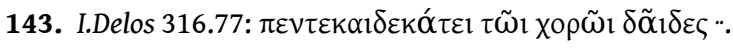




\section{ABSTRACTS}

Second-century BC Delos saw the creation of more than two dozen endowments, by men and women, Delians and aliens, and, most famously, Hellenistic royalty or their agents. Scholars agree that these underwrote festivals (mostly eponymous: The Antigoneia, Eutycheia, Philonideia, Ptolemaieia, Stesileia, etc.), and have focused on the political motivation, purpose, and effects of the dozen or so royal specimens. This paper suggests that we have misconstrued the Greek of the Delian accounts; that the endowments did not fund eponymous festivals per se, but modest recurring ritual that was established on the occasion of significant family events, especially marriage and death; that this peculiar Delian phenomenon has more to say about authentic piety than grand politics, and more in common with Hellenistic family cult than festival culture.

$\mathrm{Au} \mathrm{II}^{\mathrm{e}}$ siècle avant notre ère, Délos a vu se créer près de vingt-cinq fonds, par des hommes et des femmes, Déliens et étrangers, et, un cran plus haut dans la célébrité, par des rois hellénistiques ou leurs agents. Les chercheurs s'accordent à penser que ces fonds permettaient d'organiser des fêtes (surtout éponymes : Antigoneia, Eutycheia, Philonideia, Ptolemaieia, Stesileia, etc.), et se sont concentrés sur la motivation politique, sur les objectifs et les effets de la douzaine de cas royaux. Cet article fait l'hypothèse que le grec des comptes déliens a été mal interprété; les fonds ne finançaient pas des fêtes éponymes en soi, mais la récurrence modeste de rituels qui étaient établis à l'occasion d'événements familiaux importants, comme les mariages et les décès; ce phénomène délien particulier a davantage à dire sur la véritable piété que sur la grande politique, et il offre davantage de points communs avec le culte familial hellénistique qu'avec la culture des fêtes.

\section{AUTHOR}

\section{JOSHUA D. SOSIN}

Department of Classical Studies

Duke University, Box 90103

US - DURHAM, NC 27713-0103

joshua.sosin@duke.edu 